[Araştırma Makalesi / Research Article ]

\section{KUUA Kastamonu Eğitim Dergisi Kastamonu Education Journal}

Eylül 2019 Cilt:27 Sayı:5

kefdergi.kastamonu.edu.tr
Başvuru Tarihi/Received: 04.01.2019

Kabul Tarihi/Accepted: 07.02.2019

DOI: $10.24106 /$ kefdergi.3517

\title{
İşitme Engelli Üniversite Öğrencilerinin Mesleki Eğitiminde Uygulanan Bilgisayar Yazılımı Öğretim Modelinin İncelenmesi
}

\section{Examination of Computer Software Instructional Model Applied in Vocational Education of Hearing Impaired College Students}

\section{Öz}

\author{
Zehranur KAYA ${ }^{1}$, Ümit GiRGiN², Yıldız UZUNER ${ }^{3}$, Güzin KARASU ${ }^{4}$
}

Bu araştırmada; işitme engeli gençlerin mesleki eğitimleri sürecinde uygun öğrenme ortamları sağlanarak hazırlanacak mesleki eğitim programlarının düzenlenmesine yönelik yapılan çalışmalar incelenerek, işitme engelli bireylerin mesleki eğitiminde bir dergi çıkarma süreci ve ürünün incelenmesi amaçlanmıştır. Araştırmada mesleki eğitim sürecinde dersler arasında işbirliği ortamı oluşturularak meslek dersinde kullanılan mesleki terminoloji ve mesleki becerilerin geliştirilmesine yönelik yapılan etkinlik ve stratejilerin işitme engelli öğrencilere uygulanma süreci incelenmiştir. Araştırmanın deseni eylem araştırmasıdır. Araştırmanın katılımcılarını 2008-2009 eğitim öğretim yılında Engelliler Entegre Yüksekokulu, Grafik Lisans Programı birinci sınıfina devam eden on işitme engelli genç, makalenin birinci yazarı olan araştırmacı, dil derslerinden sorumlu öğretim elemanı, geçerlik ve güvenilirlik komitesinin öğretim elemanları oluşturmaktadır. Araştırma "Hazırlık" ve "Uygulama-Ürün Geliştirme" olmak üzere iki süreçten oluşmuştur. Araştırma verileri; videoteyp kayıtları, geçerlik ve güvenilirlik komitesinin toplantı kayıtları ve tutanakları, ders planları, değerlendirmeler ve öğrenci ürünleri oluşturmaktadır. Araştırma sürecinde işitme engelli gençlerin mesleki eğitiminde bir model oluşmuştur. Bu model doğrultusunda yürütülen derslerin öğrenciler için yararlı olduğu gözlenmiştir. Araştırma sürecinin sonunda meslek dersinde öğrenilen bilgisayar yazılımına yönelik öğrencilerin; yazılımı uygulama becerilerinin ve yazılımın mesleki dilini kullanma becerilerinin geliştiği belirlenmiştir.

Araştırma ülkemizde işitme engelli öğrencilerin yüksekokul düzeyinde mesleki eğitimleri için öncü çalışmadır. Araştırmada oluşturulan model ülkemizde ve yurt dışında işitme engelli gençlere mesleki eğitim veren diğer eğitim kurumlarındaki derslerde kullanılarak sınanabilir.

Anahtar Kelimeler: bilgisayar yazılımı öğretimi, dengeli okuma yazma öğretimi yaklaşımı, disiplinlerarası çalışma, işitme engelliler eğitimi, mesleki eğitim

\section{Abstract}

The aim of this research is to examine the process of publishing a magazine and the magazine as a product of the process in the vocational education of hearing-impaired individuals by the investigation of studies on the organization of vocational educationprograms through suitable learning environments for hearing-impaired teenagers. In the research, the application process of activities and strategies, which were utilized to develop vocational skills and terminology in the field course through cooperationof the courses in education process, on hearing-impaired students was examined. The research was designed as an action research. The participants of the research consisted of ten first year students of Graphic Arts program of the School for the Handicapped(SFH) in the school year of 2008-2009, the researcher, who was the primary author of the present article, an instructor, who was responsible from language course, and the members of trustworthiness committee (validity and reliability committee). The researchconsisted of two main processes; "preparation" and "application-product development." The research data were collected through videotape recordings, meeting records and official reports of validity and reliability committee, course schedules, evaluations andstudent products. In the research process, a model had been formed in vocational education of hearing-impaired students. It was observed that conducted courses were benefical for students. At the end of the research, considering the computer software, whichwas taught in field course, improvements in students' application skills and technical langugae usage of the software were determined.

This research is a pioneering work for vocational education of hearing-impaired students at collage level, in Turkey. The developing model of this research can be tested by using in courses of other educational institutions providing vocational training to hearing-impaired teenagers in our country and in abroad.

Keywords: balanced literacy instructional approach, education of hearing impaired, instructing software, vocational education

1. Anadolu Üniversitesi, Engelliler Entegre Yüksekokulu, Eskişehir, Türkiye; https:/orcid.org/0000-0003-1697-219

2. Anadolu Üniversitesi, Eğitim Fakültesi, Eskişehir, Türkiye; https:/orcid.org/0000-0002-2395-0733

3. Anadolu Üniversitesi, Eğitim Fakültesi, Eskişehir, Türkiye; https:/orcid.org/0000-0001-6477-2593

4. Anadolu Üniversitesi, Engelliler Entegre Yüksekokulu, Eskişehir, Türkiye; https:/orcid.org/0000-0003-4666-6062

Atıf / Citation: Kaya, Z., Girgir, Ü., Uzuner, Y. \& Karasu, G. (2019). İşitme engelli üniversite öğrencilerinin mesleki eğitiminde uygulanan bilgisayar yazılımı öğretim modelinin incelenmesi. Kastamonu Education Journal, 27(5), 2293-2310. doi:10.24106/kefdergi.3517 


\section{Extended Abstract}

Introduction : College education is one of the important steps for professional development for both normally developing and hearing-impaired students. The School for the Handicapped $(\mathrm{SfH})$ is the only higher education institute providing hearing-impaired students professional education in Turkey. The school curriculum has been designed in order for hearing impaired students would attend and be successful in their jobs that are related to their professional education. Recent research has provided evidences that hearing impaired individuals get benefits from the literacy instructions providing students meaningful, functional and purposeful literacy environments (Karasu G., 2011; Schirmer, 2000; Thompson, 1981; Uzuner, Girgin, Kaya, Karasu, Girgin, Erdiken, Cavkaytar ve Tanrıdiler, 2011). The educational programs designed for hearing impaired students' professional development must stress the importance of language and literacy skills. Based on the research it has been reported that among the literacy instruction approaches the Balanced Literacy Instructional Approach (BLIA) has been proved to be beneficial for the literacy skills of hearing impaired students (Asselin, 1999; Fountas ve Pinel, 1996; Pearson, Raphael, Vicki ve Madda, 2007; Pressley, Roehrig ve Bogner, 2002; Schirmer, 2000; Schirmer, 2010; Tompkins, 1997). The purposes of Vocational Education are providing appropriate instructional environment, improving the necessary skills, and developing target behaviors (Pressley vd., 2002; Schirmer, 2000; Karasu G., 2011; Uzuner vd., 2011).

In Professional education, interdisciplinary, collaborative educational programs are important. One of the activities designed based on the BLIA principles is publishing the school magazine.

Although there are evidences about the appropriateness of application of the activities to hearing impaired students' literacy skills based on BLIA, there was a strong need to know more about how hearing impaired students acquire professional knowledge and skills. Moreover, it is important to examine the professional programs at $\mathrm{SfH}$ in order to understand its impacts on hearing impaired students' language and professional knowledge and skills. One of the professions hearing impaired students would be trained is "Graphic Arts" at SfH. The program has "Page Design" course. In this course the students are taught how to publish newspaper, magazine and etc. by utilizing particular software. During this research project QuarkXPress was instructed.

Method: The purpose of this study was to create collaborative and interdisciplinary educational environments at Page Design Course at the $\mathrm{SfH}$ and analyze its impacts on the hearing-impaired youths' professional language and skills (Ferrance, 2000). Consistancy of the research method with the research purposes and suitability of it to describe the process in detail are important. Since action research is a process oriented approach and has ability to provide indepth explanation of working process, it was determined as suitable for this kind of studies (Mills, 2003; Henning, Stone ve Kelly, 2009). For that reason, the research was designed as an action research.

Results: During the study effort, various academic and software problems were solved and gradually an interdisciplinary, collaborative professional instructional model has emerged. The students seemed to gain benefits from this instructional model. The interactions occurred among the students and the instructors have increased. The students improved in their use of software and its terminology. These skills are important for their future professional lives. They were all competent for their occupational knowledge and skills. The students showed evidenced that they learned how to use the commands (push button), read aloud the commands (pronounce), tell, write and read the function of the commands, how to match the English commands to Turkish meanings, explain the operation of the Software. Overall, they were all competent for their occupational knowledge and skills. They said they were proud of being responsible for publishing the school magazine by acquiring many knowledge and skills necessary for their professions.

Recomendations: This project is the pioneer in the college level occupational education for hearing impaired students in Turkey. The model emerged during the course of the project would be utilized to other occupational education environments of hearing-impaired individuals in and abroad the Country. 


\section{Giriş}

Mesleki eğitim; bireyleri ilerideki mesleklerine hazırlamak amacıyla yapılan etkinlikler olarak tanımlanmaktadır (Alkan, Doğan ve Sezgin, 2001; Prosser ve Quigley, 1949). Mesleki eğitim sürecini tamamlayan bireylerin; iş ortamlarının beklentilerini karşılamaları amacıyla, meslekleriyle ilgili temel yeterlik ve becerilere sahip olmaları beklenmektedir. Bu durum bireylerin işe yerleşmelerinde önemli rol oynamaktadır (OECD, 2010; SCANS Report, 1991). Bireyleri yaşama hazırlamak amacıyla mesleki eğitimin amaçları: Uygun öğrenme ortamının sağlanması, gerekli bece-rilerin geliştirilmesi ve istenilen davranışların oluşturulması olarak sıralanmaktadır (Alkan, Doğan ve Sezgin, 2001). Mesleki eğitim açısından bu amaçların gerçekleştirilebilmesi için; öğrenmenin işlevsel olması, ihtiyaçlar doğrultusunda öğrenme amaçlarının öğrencilere açıkça verilmesi ve öğrencilerin çevrelerinde bulunan aile ve arkadaşlarının eğitim sürecini desteklemesi beklenmektedir (Pea, 1989, Akt. Berryman, 1991). Mesleki eğitimin yaşam boyu öğrenmeyi ge-rektirdiği düşünüldüğünde Avrupa Komisyonu (2007)'nun yaşam boyu öğrenme sürecinde önerdiği; işbirlikli çalışma, öğrenme talebine bakış, yeterli kaynak, öğrenme olanaklarına erişimin kolaylaştrılması ve öğrenme kültürü oluşturmak başlıklarında toplanan stratejilerinin de incelenmesi yerinde olacaktır.

Amerikan Çalışma Bakanlığı'nın 1991 yılında hazırlamış olduğu “The Secretary's Commission on Achieving Ne-cessary Skills (SCANS)" adlı raporda çok geniş bir iş aralığında; çalışanlarla, iş sahipleriyle, iş bulma kurumlarıyla, sendikalarla, mağaza, imalathane ve alışveriş merkezi müdürleriyle görüşmeler ve toplantılar yapılmıştır. Bu raporda iş gücü olarak nitelendirilen mesleki eğitim almış bireylerden beklenenler "Temel yeterlikler" ve "Temel beceriler" olmak üzere iki ana grupta toplanmıştır. Bu iki ana grupta yeralan sekiz temel özellik mesleki eğitim programlarından mezun olan gençlerin iş bulmalarına yönelik olarak eğitim programlarının düzenlenmesi açısından dikkate değerdir. Bu özellikler işyerleri ile okulların arasındaki boşluğa köprü olması bakımından da önemlidir. Raporda belirtilen temel beceri ve niteliklerin kazandırılmasına yönelik olarak hazırlanan mesleki eğitim programının verimli ve etkili olabilmesi için bazı temel özellikleri taşıması gerekmektedir. Bu temel özellikler şu şekilde sıralanabilir: İ̧̧ ortamlarına transfer edilebilir becerilerin kazandırıması, mesleki eğitim programın sürekli ve sistematik olarak değerlendirilmesi, uygulama firsatlarına yer verilmesi, yaşam boyu devam etmesi ve okul-iş ortamı işbirliğinin kurulması (Campbell, 1997). Bu özellikleri işitme engelli bireylerin mesleki eğitimi açısından düşündüğümüzde hazırlanan mesleki eğitim programlarının taşıması gereken özellikler şu şekilde sıralanabilir: Mesleki metinleri okuma ve yazma, okuduğu mesleki metinleri anlama, mesleki becerileri kazandırma ve mesleki bilginin kullanımı konularında gereken desteği sağlaması. Raporda belirtilen, mesleki nitelik ve becerileri kazandıırken aynı zamanda mesleğin dilini kullanmayı da öğrenmeleri gerekmektedir. Mesleki eğitim sürecinde kullanılan yazılı materyallerin okunup anlaşılabilmesi için yapılacak eğitimin niteliği ve önemi açıktır. Uygun mesleki eğitim programları geliştirildiğinde ve bu programlarda yer alan işitme engelli bireyler için uygun destekler sağlandığında öğrenebilecekleri ve işitme engelli bireylerin mesleki eğitimlerinin daha nitelikli olacağı araştırmalarda belirtilmektedir (İçden, 2003; Karasu G., 2011; Uzuner, İçden, Girgin, Beral ve Kırcaali-iftar, 2005; Uzuner, Girgin, Girgin, Erdiken, Karasu, Kaya, Cavkaytar ve Tanrıdiler, 2011).

\section{İşitme Engelli Gençlere Yönelik Mesleki Eğitim Programlarının Düzenlenmesi}

Eğitim programları "niçin?", "ne?", "nasıl?" ve "sonuç?" sorularına yanıt veren dört temel öğeden oluşmaktadır. Bu öğeler; amaçlar, içerikler, uygulama ve ölçme-değerlendirme başlıklarında incelenebilir (Alkan, 1974; Mager ve Beach, 1967; Sezgin, 1994). Mesleki eğitimin karmaşık yapısı, programlarının çeşitliliği ve programların kendine özgü özelliklerinin bulunması nedeniyle, mesleki eğitim programlarının hazırlanmasında; amaçların belirlenmesi, hangi temel beceri ve yeterlikte bireyin yetiştirileceğine yönelik olarak içeriklerin hazırlanması, öğretimin planlanması-uygulanması ve öğretimin değerlendirilmesi sistematik olarak incelenmeli ve geliştirilmelidir (Alkan, 1974; Mager ve Beach, 1967).

İşitme engelli bireylerin mesleki eğitimine yönelik olarak hazırlanacak mesleki eğitim programlarının mesleki eğitimin hedeflerini yansıtması gerekmektedir. Aynı zamanda işitme engelli bireylerin iş bulmaları, iş ortamlarında kendine güvenmeleri ve meslektaşlarıyla mesleki iletişim kurabilmeleri için mesleki eğitim programlarının içinde mesleki terminolojiye yer verilmesi önemlidir. Bu bağlamda mesleki yeterliklerin artırılması amacıyla meslek derslerini yürüten öğretim elemanları ile dil-okuma-yazma derslerini yürüten öğretim elemanlarının işbirliği yapması gerekmektedir. Bu işbirliğinin; işitme engelli öğrencilerin mesleki bilgi ve mesleki terminolojiyi öğrenmelerine yardımcı olacak şekilde derslerin birbirini desteklemesiyle ve bütünleştirilmesiyle uygulanması önerilmektedir (Karasu G., 2011; Schirmer, 2000; Thompson, 1981; Uzuner vd., 2011).

İşitme engelli bireylere yönelik mesleki eğitim programlarının düzenlenmesi sürecinde yapılması gerekenler; işitme engellilere yönelik mesleki eğitim programlarının öğeleri; amaçlar, içerik, uygulama ve ölçme-değerlendirme başlıklarında incelenmiştir. 


\section{Amaçlar}

Uygulanan mesleki eğitimin niteliğini artırmak amacıyla etkili bir öğrenme ortamının hazırlanması gerekmektedir. Mesleki eğitimin eğitsel yönünden tüm okul programlarında yararlanmak ve mesleki eğitimi iş dünyasındaki işlere göre güncellemek mezunların iş bulmaları açııından önemlidir. Bu nedenle mesleki eğitimin amaçları eğitim programlarına yansıtılmalıdır (Alkan, Doğan ve Sezgin, 2001; Campbell, 1997; Fer, 2000). Bu durumda mesleki dil ve okuma-yazma becerilerinin öğretilmesinde kullanılan okuma-yazma yaklaşımları önem kazanmaktadır. Okuma yazma eğitiminde Dengeli Okuma Yazma Öğretimi Yaklaşımı (DOYÖY)'nın önemi alan yazında vurgulanmaktadır (Asselin, 1999; Fountas ve Pinel, 1996; Pearson, Raphael, Vicki ve Madda, 2007; Pressley, Roehrig ve Bogner, 2002; Schirmer, 2000; Schirmer, 2010; Tompkins, 1997). DOYÖY'ün işitme engellilerin de okuma-yazma ihtiyaçlarına yanıt verdiği araştırmalarda belirtilmektedir (Pressley vd., 2002; Schirmer, 2000; Karasu G., 2011; Uzuner, İçden, Girgin, Beral ve Kırcaali-iftar, 2005; Uzuner vd., 2011).

DOYÖY anlam temelli Tüm Dil yaklaşımı (Whole Language) ile beceri temelli Beceri Öğretimi Yaklaşımı (Skill Based Approach)'nın birleşimidir. Anlam temelli öğretim; öğrenciye daha fazla sorumluluk veren öğrenci merkezli bir öğretimdir. Bu yaklaşım ile sözcüklerin anlamına, cümlelere, paragraflara ve bağlamın tümünden anlam çıkarmaya odaklanılmaktadır. Kişilerin yeterli okur-yazar olabilmeleri için, okudukları metinleri ve yazdıkları yazıları kendi yaşamlarıyla ilişkilendirmelerinin önemli olduğu vurgulanmaktadır. Anlam temelli öğretim yaklaşımları anlamayı ve metnin tümünü kullanmayı vurgulamaktadır. Beceri temelli yaklaşımlar ise ayrı ayrı becerilere odaklanmaktadır. Schirmer (2010) DOYÖY'de öğretmenlerin, öğrencilerin ve materyallerin rollerini açıkça tanımlamıştır. Schirmer (2010)'a göre; öğretmenler öğrencilerin ön bilgilerini kullanarak yeni becerileri kullanmalarına olanak vermeli ve becerileri doğrudan, açık ve sistematik bir şekilde öğretmelidir. Öğrenciler eğitime aktif olarak katılmalıdır. Materyaller öğrencilerin yeni becerileri kullanmalarına firsat verecek şekilde hazırlanmalı ve anlamayı geliştirmelidir. DOYÖY'ün temelinde yer alan ilkeler şu şekilde sıralanabilir (Cramer, 2004; Reutzel ve Cooter, 1999; Schirmer, 2000; Tompkins, 1997):

- Alıcı ve ifade edici dil becerileri birlikte geliştirilmelidir.

- Yazılı dilin anlamına gerçek bir bağlamda odaklanılması önemlidir.

- Sınıflar okuma ve yazmanın kullanım yoluyla edinildiği öğrenciler topluluğudur.

- Öğrencilere seçenekler ve sahiplenme şansı verildiğinde motive olurlar.

- Yetkin okur-yazar davranışının geliştirilebilmesi için yeni öğrenen bireylere ya da yetersiz okurlara model olunan eğitim ortamlarının düzenlenmesi önemlidir.

- Okuma-yazmanın gelişiminde eğitim-öğretim programındaki tüm derslerin bütünleştirilmesi önemlidir.

- Öğrencilerin kendi öğrenmelerinden haberdar olduğu ve öğrenmelerini kontrol etmelerinin sağlandığı eğitim ortamlarının hazırlanması önemlidir.

- Ürün ve ürünün gerçekleştirilme süreci önemlidir.

DOYÖY'ün ilkeleri incelendiğinde; Pea (1989)'nin ve Alkan, Doğan ve Sezgin (2001)'nin belirttiği mesleki eğitim amaçları ile uyuştuğu, aynı zamanda daha geniş bir bakış açısı sağladığı görülmektedir. Bu amaçla DOYÖY ilkeleri mesleki eğitim programlarının hazırlanmasındaki amaç, hedef, ilke ve özelliklere göre yorumlanarak şu şekilde açıklanabilir:

- İşgücüne kattlan bireylerin mesleki okuma-yazma, hesaplama, dinleme ve konuşma temel becerilerinin yanı sıra yaratıcı düşünme, karar alma, problem çözme, görselleştirebilme, nasıl öğreneceğini bilme ve mantıksal düşünme becerilerini de geliştirmesine yönelik eğitim ortamları hazırlanmalıdır.

- Temel becerilerin geliştirilmesine yönelik olarak gerçek bağlamlarda mesleki okuma yazma çalışmaları gerçekleştirilmelidir.

- Mesleki eğitim sürecinde sınıflar mesleki okuma ve yazmanın gerçekleştirildiği birer topluluk olarak görülmelidir.

- Öğrenci merkezli mesleki eğitim programlarında öğrencilere seçim ve sahiplenme için şans verilmesi motivasyonu sağlar.

- Anlamlı ve aktif uygulamalarda ortaya çıkan ürünün/çıktıların gerçekleşme süreci ve çıkt/ürün önemlidir.

- Mesleki okuma-yazma ve mesleki gelişim için gerekli stratejilerin kullanıldığı eğitim ortamları düzenlenmelidir.

- Mesleki okuma-yazma ve mesleki eğitim bütünleşmiş (disiplinlerarası) öğretim programının bir parçasıdır.

- Öğrenciler eğitim amaçları konusunda bilgilendirilmeli ve öğrencilerin kendi öğrenmelerinin farkında olduğu ve kendilerini kontrol etmelerinin sağlandığı eğitim ortamları hazırlanmalıdır.

- Mesleki eğitimde yaşam boyu öğrenme ve kendini geliştirme hedeflenmelidir.

Yukarıda açıklanan ilkeleri Mesleki Eğitim Programlarının Illkeleri (MEPi) olarak isimlendirebiliriz. MEPi doğrultusunda hazırlanan mesleki eğitim programlarının; hem normal işiten gençler hem de işitme engelli gençlerin öğrenme süreçlerini olumlu yönde etkileyeceğini söyleyebiliriz. 


\section{İçerik}

Mesleki eğitim programının hazırlanması amaçlandığında; iş dünyasının gereksinimlerine göre planlanan eğitim yaşantılarının kazandıııması beklenmektedir (Alkan, 1987; Mager ve Beach, 1967). İ̧̧itme engelli gençler için hazırlanan mesleki eğitim programlarının OECD (2010) raporunda belirtilen mesleki eğitim programlarının içeriğinde bulunması gereken özellikler ile desteklenmelidir. Aynı zamanda, işitme engelli öğrencilerin dil ve okuma-yazma sorunları nedeniyle, meslek derslerinin dil dersleriyle desteklenmesi şeklinde hazırlanması önerilmektedir.

Mesleki eğitim sürecinde mesleki okur-yazarlık, iş ortamlarında artan bir değere sahiptir. Bu nedenle mesleki eğitim programları bu becerilere yeterli ağırlığı vermelidir. Mesleki okuma ve mesleki yazma kavramları birbiriyle ilişkilidir. DOYÖY'Ün de vurguladığı gibi bir alandaki gelişim diğerini etkilemektedir. Öğrenciler mesleki eğitim programlarında yazmayla olduğu kadar okumayla da ilgilenmelidir. Bu bağlamda; mesleki eğitim programlarının içeriğinde mesleki okuma ve yazma etkinliklerinin birlikte yürütülmesi önemlidir. Ayrıca öğrencilerin meslekleriyle ilgili teknoloji okur-yazarlığının da geliştirilmesi gerekmektedir. Bu çalışmalar ile desteklenen mesleki eğitim programlarının bireylerin kişisel niteliklerini geliştirmelerine firsat vereceği düşünülmektedir.

Mesleki eğitim programlarında yer alan öğrenciler aynı zamanda kendilerini yetiştirmek amacıyla mesleklerinin gerektirdiği okumaları yapabilmelidir. Bu amaçla tasarım okuma, bilgisayar okur-yazarlığı, teknoloji okur-yazarlığı gibi mesleki amaçlara yönelik okur-yazarlık çalışmaları, teknolojinin kullanılması, tasarım üzerinde görülmesi gereken detayların algılanması gibi niteliklerin mesleki eğitim sürecinde geliştirilmesi SCANS (1991) raporunda belirtilen yeterlikler ve Avrupa Komisyonu (2007)'nun belirttiği yaşam boyu öğrenme stratejileri açısından da gereklidir. Üniversite düzeyindeki işitme engelli gençlerin mesleki eğitim programlarının içeriğinde, mesleki okuma yazmalarının geliştirilmesi amacıyla yaşlarına uygun ve meslekleriyle bağlantılı metinler üzerinde çalışılması öğrencilerin motivasyonlarını artırması yönüyle de önemlidir. Mesleklerine yönelik olarak yapılacak çok çeşitli okuma çalışmaları işitme engelli öğrencilerin mesleki terminolojilerinin gelişmesini sağlayacaktr. Bu süreçte DOYÖY ile yapılan etkinlik ve stratejilerin mesleki eğitim programlarının içeriklerinde yer alması gerekmektedir (Karasu G., 2011; Uzuner, İçden, Girgin, Beral ve Kırcaali-iftar, 2005; Uzuner vd., 2011). DOYÖY ilkelerine göre; okuma yazma öğrenmede öğrencilerin çok ve çeşitli okuma-yazma firsatına, deneyimlerini paylaşmalarına ihtiyaçları bulunmaktadır. Okuma ve yazmanın; öğrenme, düşünme, gelişme ve değişme için birer araç olduğu unutulmamalıdır (Cramer, 2004; Schirmer, 2000).

İşitme engelli öğrenciler üniversite eğitimlerine ulaştklarında, hazırlanan mesleki eğitim programlarının üst bilişsel farkındalıklarını artırmaya yönelik olarak hazırlanması iş hayatına uyum sağlamaları ve kendilerini geliştirmeleri açısından önemlidir. Bu bağlamda; hazırlanan üniversite düzeyindeki mesleki eğitimde; işitme engelli öğrencilerin yaşlarına ve dil düzeylerine uygun çalışmalar planlanması üst bilişsel becerilerini geliştirmelerine firsat verebilir (Karasu G., 2011; Uzuner vd., 2011). DOYÖY ilkelerine göre; okuma ve yazma becerileri öğrenme ve düşünme alanında kullanılmalıdır. Alan öğretmenleri aynı zamanda okuma-yazma öğretmenidirler. Bu nedenle öğretim programındaki derslerin birbirlerini desteklemesi gerekmektedir (Rief ve Heimburge, 2007). Bu amaçla mesleki eğitim programlarının içeriğinde disiplinlerarası öğretimden yararlanılabilir. Bu bağlamda, hazırlanan mesleki eğitim programlarının içeriğinde meslek derslerinin yanı sıra dil derslerinin de yer alması ve meslek ve dil derslerinin birbirini destekleyecek şekilde disiplinlerarası çalışmaların yapılması DOYÖY ve dolayısı ile MEPI açısından da gereklidir.

\section{Uygulama}

Mesleki eğitim programları içindeki öğrencilerin edindikleri becerilerin kullanımına yönelik olarak sürecin nasıl gerçekleştiği önemlidir. Öğrenciler için hazırlanan anlamlı ve aktif ortamlar onların mesleki becerilerini geliştirmeleri açısından gereklidir (Alkan, Doğan ve Sezgin, 2001; Campbell, 1997). Mesleki eğitim sürecinde gerçek bir ürüne odaklı olarak gerçekleştirilen eğitim sürecinin öğrencilerin mesleki gelişimlerini olumlu etkileyeceği araştırmalarda belirtilmektedir (Campbell, 1997; Pea, 1989, Akt. Berryman, 1991). Mesleki eğitim sürecine DOYÖY'ün ilkeleri açısından bakıldığında, mesleki okuma-yazmanın geliştirilmesi öğrencilerin mesleki gelişimleri için önemli bir gerekliliktir (SCANS, 1991). Mesleki eğitim sürecinin öncesinde alınan eğitimde öğrencilerle yapılan etkili okuma-yazma çalışmalarının, mesleki eğitim programlarına da yansıtılarak etkili mesleki okuma-yazma alanında da kullanılması mesleğin temel beceri ve yeterliklerinin gelişmesine yardımcı olacaktır (SCANS, 1991).

İşitme engelli öğrencilerin koklear-implant kullanmaları ve işitsel sözel eğitime erken başlamaları okuma becerilerini olumlu yönde etkilemektedir. Ancak hala işiten yaşıtlarından okuma becerileri açısından geride oldukları bilinmektedir (Karasu H.P., Girgin ve Uzuner, 2012). Bu durum göz önüne alındığında, eğitim süreci boyunca gerçekleşen etkinliklerin neler olduğu ve nasıl gerçekleştiği ile ilgili süreç bilgisinin paylaşılması; bu sürecin geliştirilerek farklı düzeydeki ve yaşlardaki öğrencilerle, farklı derslerde ve farklı etkinliklerle tekrarlanması ve bu konuda yapılacak çalışmaların geliştirile- 
rek yaygınlaşması yönüyle önemlidir. Bu açıdan bakıldı̆̆ında süreç; süreç sonunda ortaya çıkan ürün kadar önemlidir. Ürüne yönelik olarak yapılan çalışmaların mesleki eğitim sürecinde işitme engelli öğrenciler için olumlu sonuçlar verdiği bilinmektedir (Karasu G., 2011; Uzuner vd., 2011). İ̧itme engelli gençlere yönelik olarak hazırlanacak mesleki eğitim programlarında mesleki bilginin nasıl öğretileceği konusunda DOYÖY'ün etkinlik ve stratejileri incelenmelidir.

\section{Mesleki Eğitimde Dengeli Okuma Yazma Öğretimi Etkinlikleri}

DOYÖY sınıflarında kullanılan temel etkinlikler; sesli okuma, paylaşılan okuma, rehberli okuma, bağımsız okuma, model olunarak ya da etkileşimli yazma, paylaşılan yazma, rehberli yazma, bağımsız yazma olarak belirtilmektedir (Fountas ve Pinnell, 1996; Schirmer, 2000). DOYÖY içindeki etkinlikler, farklı düzeydeki öğrencileri destekler ve bağımsız okur-yazar olma yolunda gittikçe azalan öğretmen desteğini gerektirir (Fountas ve Pinnell, 1996). Etkinliklerin yapılabilmesi ve geliştirilebilmesi için stratejilere ihtiyaç vardır. Öğretmenin görevi, stratejileri öğrencilerinin düzeylerine ve gereksinimlerine göre düzenlemek ve uygulamaktı. Okuma eğitimi kaynaklarında işiten ve işitme engelli bireylere yönelik olarak etkileri araştırılmış okuma anlama stratejileri bulunmaktadır (Akçamete, 1999; Buehl, 2001; Carnine, Silbert \& Kameenui 1996; Graham ve Wong, 1993; Harrel ve Jordan, 2002). Kullanılan bu stratejiler; okulda başarının artmasına yardımcı olurken, öğrenilen mesleki bilginin mesleki eğitim sonrasında iş ortamlarında daha etkili kullanılmasına ve yaşam boyu öğrenme sürecinde bu bilgilerin güncellenmesinde bireylere yardımcı olabilecektir. Yapılan araştırmalarda işitme engelli öğrencilerin de, okuduğunu anlama stratejilerini öğrenebildikleri ve kullanabil-dikleri belirtilmektedir. Ancak, işitme engelli öğrencilerle stratejilerin farklı etkinliklerle tekrar edilmesi öğrenilen yen bilginin kalıcılığının sağlanması yönüyle önemli bir gerekliliktir (Girgin,1999; Karasu G., 2011; Uzuner, İçden, Girgin, Beral ve Kırcaali-iftar, 2005; Uzuner vd., 2011; Walker, Munro ve Rickards; 1998).

\section{Mesleki Eğitimde Kullanılabilecek Dengeli Okuma Yazma Öğretimi Yaklaşımı Stratejileri}

Stratejiler çok farklı şekillerde kullanılabilir, önemli olan öğrencilerin bireysel ihtiyaçlarına göre belirlenmesi ve uygulanmasıdır (Hagood, 1997). Bu bağlamda DOYÖY'ün ön bilgilerin harekete geçirilmesi ve sözcük dağarcığının geliştirilmesine yönelik stratejileri kullanılabilir. Ön bilgi; okuyucunun metni anlamlandırabilmesi için kullandığı uzun süreli hafizasındaki bilgilerdir. Okuma çalışmasına başlamadan önce yapılan ayrıntılı ve irdeleyici çalışmalar, okuyucuların metne ve konuya ait önemli ve birbiriyle bağlantılı bilgileri hatırlamasına yardımcı olmaktadır. Ön bilgilerin harekete geçirilmesi, okumada başarılı olmak için gerekli bir stratejidir (Cramer, 2004; Irvin, Buehl ve Klemp, 2007; Kameenui ve Simmons, 1990; Paul, 2003).

Önceki bilginin belirlenmesi amacıyla soru-yanıt ve tahmin etme stratejileri kullanılmaktadır (Center, 2005; Luckner ve Handley, 2008). Bu açıdan bakıldığında işitme engelli gençlerin mesleki eğitiminde kullanılan mesleki metinlerin okunup anlaşılabilmesi için metinlerin içinde yer alan mesleki terminolojinin öğretilmesinde öğrencilerin ön bilgilerinin ve deneyimlerinin belirlenmesine yönelik yapılacak çalışmalar önem kazanmaktadır. Dil gelişiminde sözcük dağarcığı önemlidir ve okuma anlamanın temelini oluşturmaktadır (Bauman ve Kameenui, 2004; Hiebert ve Kamil, 2005). Sözcük dağarcığının gelişimine yönelik olarak stratejilerin kullanılması gerekmektedir (Bauman ve Kameenui, 2004). Mesleki eğitime bu açıdan baktığımızda; öğrencilerin mesleğin dilini öğrenebilmesi için uygulanacak stratejilerin; öğretimin amaç ve gereksinimleri doğrultusunda mesleki bilgiyi desteklemek için hazırlanan etkinliklerde kullanılması gerektiği söylenebilir. Schirmer (2000)'ın işitme engelli öğrenciler için etkili olduğunu belirttiği DOYÖY stratejileri; Tanımlama yapma, tahmin etme, soru-yanıt, model olma, tekrar etme, doğrudan öğretim, geribildirim verme, görselleştirme, boşluk doldurma ve anlam haritası olarak sıralanmaktadır.

Kullanılan stratejilerin yanı sıra Nagy (1988); etkili sözcük dağarcığını geliştirmeye yönelik ilkeleri; (a) bütünleştirme (Integration), (b) yeterli tekrar (Repetition), (c) anlamlı kullanım (Meaningful Use) olarak belirtmektedir. Bütünleştirme; öğrenilen sözcüklerin önceki bilgilerle birleştirilmesidir (Rupley ve Nichols, 2009). Yeterli tekrar; öğrenilen yeni sözcüklerin anlamlı bağlamlarda yeterli sayıda tekrar edilmesidir (Bauman ve Kameenui, 2004). Anlamlı kullanım ise; öğrencilerin sözcükleri anlamına yönelik olarak kullanmalarına ortam sağlanmasıdır (Bauman ve Kameenui, 2004). İşitme engelli öğrencilerin mesleki okuma-yazmalarını desteklemek amacıyla etkili sözcük dağarcığı stratejilerinin yanı sıra sözcük dağarcığı geliştirme ilkelerinden de yararlanılmalıdır. İşitme engelli öğrencilerin mesleki eğitiminde mesleki okuma-yazmalarının yanı sıra mesleğin gerektirdiği becerilerin de kazandırılması gerekmektedir. Bu amaçla yapılacak uygulamalara derslerde yeterince zaman ayrılması sağlanmalıdır (Alkan, Doğan ve Sezgin, 2001; Campbell, 1997; OECD, 2010). Becerilerin öğretilmesi amacıyla yapılacak uygulama çalışmalarııı, teorik bilginin hemen arkasından izleyen etkinlik olarak yapılması önerilebilir. Bu şekilde öğrenciler teorik olarak öğrendikleri bil-gileri, uygulama yoluyla beceriye dönüştürebilirler. Ancak derslerde yapılan uygulamalar öğrenmenin kalıcı olması için yeterli olmayacaktır. Ders sonrasında derste öğrenilen bilgilerin tekrar edilmesi amacıyla yapılan zenginleştirme etkinliği becerilerin öğrenilmesinde 
tekrarlara yer vermesi yönüyle kullanılması gerekmektedir (Jensen, 2011).

Mesleki eğitimin niteliğini artırmak amacıyla DOYÖY ilkeleri doğrultusunda kurgulanan işbirliği ile işitme engelli öğrenciler daha çok tekrar yapabileceklerdir. Yapılan tekrarların olumlu sonuçları çeşitli araştırmalarda belirtilmiştir (Karasu, 2011; Schirmer, 2000; Uzuner vd., 2011). Araştırmalar doğrultusunda; işitme engelli öğrencilere meslek derslerinde öğretilen mesleki kavramların ve mesleki becerilerin geliştirilmesi için derslerin DOYÖY ilkeleri doğrultusunda planlanmasının olumlu gelişmeler sağlayacağı söylenebilir. DOYÖY ilkeleri doğrultusunda öğretim elemanları arasındaki işbirliği amacıyla; birbirini destekleyen meslek dersleri ve dil derslerinde ortak ödevler, ortak terminoloji ve ortak konular yoluyla işbirliği yapılması sağlanabilir (Derican, 2010; Karasu, 2011; Uzuner vd., 2011). Meslek dersleri ile dil derslerinin işbirliği çalışmasına yönelik olarak "okulda yayıncılık" çalışması yapılabilir. Okulda yayıncılık çalışması tüm öğrencilerin ürüne katılması yönüyle de dikkat çekicidir. İşbirliği amacıyla yapılan bu çalışma ile öğrenciler farklı metin türlerinde okuma ve yazma çalışmaları yapabilir, birbirleriyle iletişim kurabilir, görüşmeler yapabilir, araştırmalarını raporlaştırabilir, farklı tasarımlar yapabilir, fotoğraflar çekerek bunları yazılarında kullanabilir, bilgisayar teknolojisini öğrenerek amaçları doğrultusunda kullanabilir ve yayıncılık amacıyla kullanılan bilgisayar yazııımlarını öğrenebilirler (Wang, 2008). Okulda yayıncılık çalışması öğrencilerin okuma-yazmalarını geliştirmesi açısından farklı etkinlikleri içinde barındırmasının yanı sıra DOYÖY'ü uygulamak için firsat yaratması yönüyle de önemlidir (Uzuner vd., 2011). Mesleki eğitim sürecinde mesleki okuma-yazma çalışmalarının önemi göz önünde bulundurulduğunda okuma-yazmanın geliştirilmesi amacıyla okulda yayıncılık çalışmalarının önemi daha iyi anlaşılabilir.

\section{Değerlendirme}

Mesleki eğitim programlarının hazırlanmasında; mesleki eğitimin amaçlarının belirlenmesinden sonra bu amaçlar doğrultusunda ne öğretileceği ve nasıl öğretileceği araştırılır. Eğitimin içeriğine yönelik olarak yapılan uygulama ile ortaya çıkan sonuç mesleki eğitim programlarının değerlendirilmesi ile belirlenebilir. Mesleki eğitimin amacı bireyleri ilerideki mesleklerine hazırlamaya yönelik etkinlikler gerçekleştirmektir (Alkan, Doğan ve Sezgin, 2001). Mesleki eğitim sürecinde gerçekleştirilen etkinliklerin öğrencilerin başarılarına olan katkısının ölçülmesi eğitimin başarısını artırmak amacıyla gereklidir.

Eğitim sürecinde bireylere kazandırılması planlanan davranışlar; bilgi, tutum ve beceri olarak üç biçimde incelenebilir. Bilgi ve tutum davranışın bilişsel ve duyuşsal boyutunu oluşturur. Beceri ise davranışı yapabilme ile ilgilidir. Becerinin ölçülmesi; davranışın yapılması sırasında, hazırlık ve etkinliği gözlemekle, etkinlik yapıldıktan sonra elde edilen ürünün miktar ve kalitesini ölçmekle mümkün olmaktadır. Bir işin belirtilen yönerge ile yapılabilmesi becerisinin değerlendirilmesi; davranışın yerine getirilmesi sırasında, etkinliğin gözlenmesi ve etkinlik sürecinde yapılanlar ve etkinlik sonucunda ortaya çıkan ürünün yönergede belirtilen unsurları taşıyıp taşımadığı ile değerlendirilebilir (Fidan, 1997; Yılmaz, H., 2004). Etkili bir değerlendirmenin çok yönlü olması gerekmektedir. Bu bağlamda DOYÖY'ün; hem süreci hem de ürünü yansıtmak amacıyla öğrencilerin bilgi, beceri ve tutumlarını değerlendirmek için çeşitli ve sürekli olarak değerlendirme yapabilmesi ve değerlendirmenin öğrenme ve öğretme sürecinin bir parçası olması nedeniyle çok yönlü değerlendirmeye olanak verdiği görülmektedir. Bu nedenle, mesleki eğitim programlarının ölçme-değerlendirme süreçlerinde, öğrencilerin meslekleriyle ilgili öğrendikleri bilgilerin ve mesleki becerilerin değerlendirilmesinde DOYÖY'ün değerlendirme ilkelerinden yararlanılabilir. DOYÖY'ün sistematik ve çok çeşitli teknikleri ile yapılan değerlendirmeler mesleki eğitim sürecini şekillendirilebilir. Planlı ve sistematik olarak yapılan değerlendirmeler ile mesleki eğitim programının ihtiyaca cevap verip vermediğinin kontrol edilmesi sağlanabilir.

\section{Araştırmanın Gereksinimi}

İşitme engelli öğrenciler edinecekleri mesleğin dilini okuyup yazamazlarsa; mesleğe ilişkin bilgilerini geliştiremezler, meslek dilini okuyup anlamada zorluk çektikleri için mezun olduktan sonra mesleklerine ilişkin yeni bilgilere ulaşmakta zorluk çekerler dolayısı ile mevcut bilgilerini güncelleyemezler. Aynı zamanda iş bulma konusunda yaptıkları girişimlerde kendilerini yeterince ifade edemeyecekleri de açıktır. Mesleki dili kullanamayan işitme engelli üniversite öğrencileri çalıştıkları iş ortamlarında meslektaşlarıyla kuracakları mesleki iletişimde zorluk çekerler ve öğrendikleri bilgiyi farklı alanlara transfer etmekte zorlanırlar. Bu nedenlerle mesleki bilgiyi okuyup yazabilen, mesleki bilgisini çevresindekilere anlatabilen, mesleki bilgiyi araştıı bulabilen, mesleki bilgisini farklı çalışmalara transfer edebilen mezunların yetiştirilmesi için işitme engelli gençlere yönelik olarak hazırlanan mesleki eğitim programlarının, mesleki okuma-yazma etkinliklerini içermesi gerekmektedir.

İ̧̧itme engelli gençlerin mesleki eğitim programlarında yer alan meslek derslerinin nasıl yapılacağına ilişkin araştırmaların ayrıntılı bir şekilde açıklanması, karşılaşılan sorunlar ve bu sorunlara getirilebilecek çözümler sunulması gerekmektedir. Bu nedenle yapılacak araştırmaların yönteminin bu süreci ayrıntlı bir şekilde anlatmaya uygun olması 
önemlidir. Eylem araştırmalarının sürece odaklı olması, bir çalışmanın yapılma sürecini ayrıntılı bir şekilde açıklaması ve iyileşmeyi sağlamak amacıyla döngüsel modeller kullanması nedeniyle bu tür araştırmalar için uygun olduğu görülmektedir (Bogdan ve Biklen, 2007; Cresswell, 2005; Gay, Mills ve Airasan, 2006). İşitme engelli gençler için mesleki eğitimin nasıl yapılması gerektiğine yönelik olarak mesleki eğitim programlarının hazırlanmasında DOYÖY ilkeleri ve bu ilkelerden doğan MEPI ışık tutacaktır. Ayrıca okulda yayıncılık çalışmasının; DOYÖ ilkeleri ve MEPI'nin işitme engelli bireylerin yükseköğretiminde uygulanması için bir araç olarak kullanılabileceği görülmektedir.

\section{Önem ve Amaç}

Araşttrma Anadolu Üniversitesi Engelliler Entegre Yüksekokulu'nda (EEYO) gerçekleştirilmiştir. İşitme engelli gençlere yükseköğretim aşamasında eğitim veren bir kurum olarak Engelliler Entegre Yüksekokulu'nun eğitim-öğretim programında, meslek derslerinin yanı sıra dil dersleri de yer almaktadır. EEYO'da araştırmanın gerçekleştirildiği sürede, meslek dersleri ile dil derslerinin işbirliğine yönelik bilimsel araştırmalar yapılmaktaydı (Derican, 2010; Karasu, 2011; Uzuner vd., 2011). Yapılan bilimsel çalışmaların tüm okula yayılabilmesi için araştırmaların çeşitlendirilmesi gerekmekteydi. Bununla birlikte, öğrencilere mesleki eğitimin içinde yer alan temel beceri ve temel yeterliklerin kazandırılabilmesi için mesleki okuma-yazma becerilerinin geliştirilmesi de önem taşımaktadır. Etkili bir mesleki okuma-yazma ancak; amaçlı, işlevsel ve anlamlı bir meslek dilini içeren okuma-yazma ortamı sağlandığında mümkün olabilmektedir (Karasu, 2011; Schirmer, 2000; Uzuner vd., 2011).

Engelliler Entegre Yüksekokulu öğrencilerinin dil düzeylerinin çok çeşitlilik gösterdiği belirlenmiştir. Bu durum işitme engelli bireylerin; işitme engelli olma yaşı, tanılanma yaşı, işitme kaybının derecesi, aldığı eğitimin niteliği, sosyo ekonemik düzey, aile eğitiminin alınmış olması gibi dil becerilerini belirleyen özelliklerden kaynaklanmaktadır (Tüfekçioğlu, 1998). Aynı sınıfta yer alan ve EEYO'ya çok farklı dil, okuma-yazma ve iletişim becerileriyle gelen işitme engelli öğrencilerin mesleki eğitimlerinin nasıl gerçekleştirileceği önemli bir sorundur. DOYÖY'ün ilkeleri doğrultusunda uygulanan etkinlik, strateji ve tekniklerle derslerin, bu öğrencilerin düzeylerine uygunluğu sağlanabilmektedir. Bu araşttrmanın, işitme engelli bireylerin mesleki eğitiminde gerçekleştirilecek ders ve araştırmalara ışık tutacağı düşünülmektedir.

Ayrıca, araştırma sonuçlarının EEYO'nun ders programlarının gelişmesine katkı sağlayabileceği gibi işitme engellilerin mesleki eğitimi alanında hizmet eden kurumların ders programlarının yapılandııılmasına yardımcı olacağı düşünülmektedir. EEYO'da yer alan meslek ve dil derslerinin işbirliğinin incelenmesinin mesleki eğitim veren kurumlara, öğretmen ve öğretim elemanlarına bakış açısı kazandırması beklenmektedir. Araştırma ülkemizde işitme engelli gençlere yönelik olarak yükseköğretim aşamasındaki mesleki eğitimin nasıl yapılması konusunda geliştirilen ilk çalışma olması nedeniyle ayrıca önem taşımaktadır. Araştırmanın genel amacı, MEPI ve DOYÖY ilkelerine göre işitme engelli üniversite öğrencilerine bilgisayar yazılımı öğretim sürecinin nasıl gerçekleştiğinin incelenmesidir. Bu amaç doğrultusunda makalede, mesleki eğitimde bir bilgisayar yazııımı kullanılarak gerçekleştirilen yayın çıkarma sürecinde oluşagelen model, modelin bileşenleri ve modelin işleyişi sunulacaktır.

\section{Yöntem}

Araştırma eylem araştırması olarak desenlenmiştir. Araştırmada işitme engelli gençler için DOYÖY ilkeleriyle bütünleştirilmiş MEPi temel alınmıştır. Araştırmada bilgisayar programı kullanarak bir dergi çıkarma sürecinin sistematik olarak incelenmesi ve ürünün betimlenmesi gerçekleştirilmiştir. Eylem araştırmaları sosyal bir problemi anlamak ve bir sorunu çözmek için yapılan çalışmalardır (Ferrance, 2000). Eylem araştırmasının merkezinde uygulama vardır. Eylem araştırmalarında özellikle bir problemin çözümüne yönelik olarak nitel ve nicel veri toplama tekniklerinden yararlanılır (Cresswell, 2005). Sorunu belirleme, sorunla ilgili veri toplama, toplanan verilerin değerlendirilmesi ve sorunla ilgili iyileşmeyi sağlamak amacıyla döngüsel modeller kullanılır. Bu modellerde süreç içinde kişiler konu ile ilgili düşüncelerini, bilgilerini ve çözüm önerilerini paylaşırlar. Bu şekilde araştırmanın amaçlarını gerçekleştirmek için yeni eylem planları tasarlanır (Mills, 2003; Henning, Stone ve Kelly, 2009). Eylem araştırmalarının diyalektik döngüsüne bir örnek Şekil 1'de gösterilmiştir (Mills, 2003). 


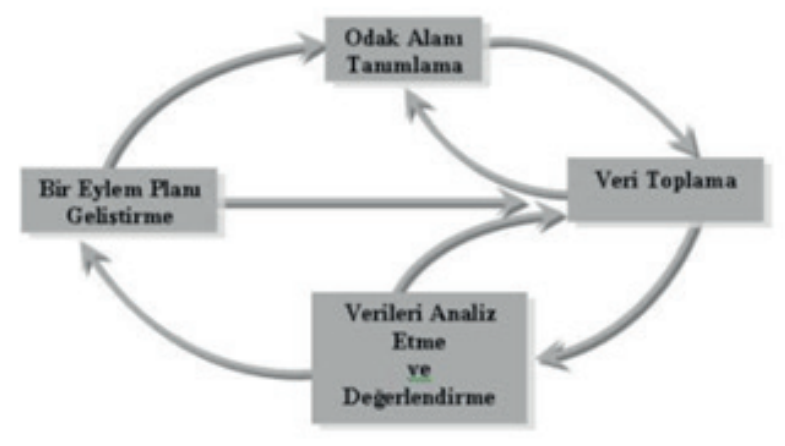

Şekil 1. Eylem araştırmalarının diyalektik döngüsü (Mills, 2003)

Bu araştırmanın temel problemini; "işitme engelli bireyler meslekleriyle ilgili olarak nasıl daha donanımlı olarak eğitilebilir?" sorusu oluşturmaktadır. Bu soru pek çok şekilde yanıtlanabilir. Yapılan kaynak taramaları; DOYÖY ve MEPI'nin bir örnekle sınanmasının uygun olacağını düşündürmüştür. Bu nedenle araştırmada işitme engelli öğrencilerin mesleki eğitimlerinin yükseköğretim aşamasında, DOYÖY ilkeleri, MEPI ve Mesleki Eğitimin Amaç ve Hedefleri göz önünde bulundurularak hazırlanan mesleki eğitimde, bir dergi çıkarma sürecinin yanı sıra dergi çıkarmak için kullanılan bilgisayar yazılımının komutlarının anlaşılması ve kullanımı (uygulanması), İngilizce komutların söylenebilmesi ve tanımlanması amacıyla meslek dersi ile dil derslerinin işbirliğinin yapısı incelenerek eylem planları geliştirilmiştir. Bu sürecin ayrıntılı bir şekilde açıklanması, süreçte yaşanan sorunlar ve sorunlara getirilen çözümlerin paylaşıması, araştırmacının veriye yakın olması ve süreci yakından takip edebilmesi ve sürecin döngüsel ve sistematik olarak incelenebilmesinden dolayı araştırma eylem araştırması olarak desenlenmiştir.

\section{Ortam}

Araştırmanın gerçekleştirildiği EEYO'nun işitme engelli öğrencilere üniversite düzeyinde mesleki eğitim veren tek kurum olması, Yüksekokul programlarında meslek derslerinin ve dil derslerinin birbirini desteklemeye izin verecek şekilde yer alması ve araştırmacının EEYO'da görev yapıyor olmasından dolayı araştırmanın EEYO'da gerçekleştirilmesine karar verilmiştir. EEYO, 1993-1994 eğitim öğretim yılında öğretime başlamıştır. Yüksekokul; işitme engellilere, yükseköğrenim kademelerinde; Grafik, Seramik, Yapı Ressamlığı ve Bilgisayar Operatörlüğü programlarında eğitim vermek, topluma üretken bireyler olarak katılmalarını sağlamak amacıyla kurulmuştur (Engelliler Entegre Yüksekokulu, 1993). EEYO'da iyi işiten kulakta enaz 50 dB sensori-neural (duyu sinirsel) tip işitme kaybı olan gençler öğrenim görmektedir. EEYO'da yeralan programların öğrenci kontenjanları 11 öğrenci ile sınırlıdır.

\section{Katilanlar}

Araştırmanın katılımcılarını 2008-2009 öğretim yılı güz döneminde Grafik 1. sınıfa kayıt yaptıran 19-26 yaş arasındaki 10 işitme engelli öğrenci, araştırmanın odak derslerini yürüten öğretim elemanları ve araştırmanın Geçerlik ve Güvenilirlik Komitesi'nin üyeleri oluşturmuştur.

Araştırmaya katılan öğrenciler bilateral sensorineural (çift taraflı duyu sinirsel tip) işitme kayıplıdır. Öğrencilerden ikisi koklear implant kullanmaktadır. Derslerde sözlü etkileşim kullanılmıştrr. Sözlü etkileşim sürecinde gerektiğinde tahtaya yazarak, gerektiğinde jest ve mimik kullanarak öğrencilere ipucu sağlanmıştı. İngilizce sözcüklerin okunuşlarının çalışıımasında, okunuşun tahtaya yazılması, bazı mesleki sözcüklerin ifade ettiği anlama ait şeklinin tahtaya çizilmesi gibi tekniklerle sözlü etkileşim desteklenmiştir. Genel olarak odak sınıftaki öğrencilerin; sıraalma, söyleşi yapma, dinleme becerilerinde ve günlük yaşantrya yönelik sözcükleri yazılı ve sözlü olarak kullanmada sorun yaşamadığı görülmüştür. Öğrenciler araştırmanın amacı ve uygulaması sürecinde karşılaşacakları durumlar, bulguların yayınlanması ve gerektiğinde araştırmadan ayrılabilecekleri gibi konularda bilgilendirilmişlerdir (Biber ve Leavy, 2011; Ryen, 2011). Öğrencilerin eğitim ve işitme kayıplarına yönelik bilgiler Tablo 1'de yer almaktadır. 
Tablo 1. Öğrenci özellikleri

\begin{tabular}{lcccc}
\hline Öğrenci**** & Yaş/Cinsiyet & Iş̧itme Kaybı (İyi işiten kulak) (dB) & İşitme Kaybının Başladığı Yaş* & Cihaz Kullanma Yaşı* \\
\hline Yalçın & $21 / E$ & 110 & Doğuştan & $3-4$ Aylık \\
Tolga** & $22 / E$ & 107 & 6 Aylık & 11 Aylık \\
İhsan*** & $20 / E$ & 105 & 72 Aylık & 72 Aylık \\
Nimet & $22 / K$ & 95 & 12 Aylık & 12 Aylık \\
Leyla & $20 / K$ & 102 & 9 Aylık & 10 Aylık \\
Deniz & $20 / K$ & 102 & 10 Aylık & 10 Aylık \\
Gürbüz & $19 / K$ & 103 & 18 Aylık & 18 Aylık \\
Filiz*** & $19 / K$ & 121 & Doğuştan & 7 Aylık \\
Doğan & $20 / E$ & 156 Aylık & Takmıyor \\
Muhsine & 22/K & 87 & 30 Aylık & 30 Aylık \\
Hülya & 20/K & 104 & Doğuştan & 36 Aylık \\
\hline
\end{tabular}

* Öğrencilerin beyanları esas alınmıştır. ** Kayıt yaptırdıktan sonra derslere gelmeyen öğrenci

*** Cl: Koklear implantlı öğrenci $\quad * * * *$ Öğrencilerin isimleri değiştirilmiştir.

Araştırma verileri EEYO'da "Sayfa Tasarımı" meslek dersini yürüten makalenin birinci ve "Yazılı ve Sözlü Anlatım I" ve "Grafik Tasarım Meslek Dili I" derslerini yürüten makalenin dördüncü yazarı öğretim elemanları tarafindan toplanmıştr. Araştırmacılar işitme engelliler eğitimi konusunda araştrmanın yapıldığı yılda on sekiz ve on dört yıllık deneyimlere sahiptiler. Araştırmacılar nitel araştırmalar ile ilgili dersleri alarak alanları ile ilgili konferanslara katılmış ve eylem araştırması projelerinde araştırmacı olarak yer almışlardır.

Geçerlik ve Güvenilirlik Komitesi: Araştırmanın konusu hakkında genel bilgiye sahip ve nitel araştırma yöntemleri konusunda uzman kişilerin, yapılan araştırmayı incelemesi inandırıcılık konusunda alınan önlemlerden biridir (Creswell, 2005; Henning, Stone ve Kelly, 2009; Mills, 2003). Araştırmanın Geçerlik ve Güvenilirlik Komitesi izleme toplantılarıyla inandırıcılık konusunda araştırmanın sistematik olarak denetlenmesini sağlamıştır. Araştırmada öğretimi planlanan mesleki sözcüklerin geçerlik çalışmaları meslek derslerinden sorumlu araştırmacı ve "Grafik Tasarım II" dersinden sorumlu EEYO’nun Grafik Lisans Programının sorumlusu öğretim elemanı tarafindan yapılmıştır.

Veri Toplanma ve Analiz: Araştırma sürecinde nitel ve nicel veri toplama yöntem ve tekniklerinden yararlanılmıştır. Araştirma verileri:

- Sınıf gözlemleri ve videoteyp kayıtları: "Sayfa Tasarımı" dersi için 15 hafta video kaydı, Grafik Tasarım Mesleki Dili I dersi için 13 hafta video kaydı alınmıştır.

- Geçerlik ve Güvenilirlik Komitesi ses kayıtları ve tutanakları: Araştrma sürecinde 54 toplantı yapılmıştr. Toplantılar ses kaydı ile kayıt edilmiş ve tutanakları yazılmıştr.

- Ders planları ve yansıtmalar: "Sayfa Tasarımı" dersi için 15, "Grafik Tasarım Meslek Dili I" dersi için 13 ders planı ve yansıtma yazılmıştır.

- Öğrenci ürünleri: Öğrencilerin ödevleri, değerlendirilen uygulama çalışmaları dosyalanmıştır.

- Belgeler: Öğrencilere ait odyogram ve kimlik bilgileri EEYO Öğrenci İşleri Birimi'nden edinilmiştir.

- Görüşme: 29/08/2008 tarihinde, "Grafik Tasarım II" meslek dersi öğretim elamanı ile görüşme yapılmıştr. Görüşme odyoteyp ile kayıt edilerek dökümü yapılmıştır.

Yararlanılan veri toplama araçları ve tekniklerinin geçerlikleri ve verilerin doğruluğu için uzman görüşü alınmıştr. Toplanan veriler ve elde edilen sonuçlar alanyazınla ilişkilendirilerek raporlaştrılmıştı. Verilerin toplanması ve analizi eş zamanlı olarak yapılmıştır. Veriler araştırmanın amacı doğrultusunda Geçerlik ve Güvenilirlik Komitesi'nin aldığı kararlara göre sistematik olarak döngüsel ve yansıtmalı olarak analiz edilmiştir. Araştırmada gerçekleşen işbirliğinin yapısını sunabilmek için oluşagelen modelin bileşenlerini temsil eden ve araştırmacının yürüttüğü "Sayfa Tasarımı" ve bu dersin sözcüklerini destekleyen ve dil dersi öğretim elemanının yürüttüğü “Grafik Tasarımı Meslek Dili I” dersinde uygulanan işbirliği betimlenmiştir.

\section{Araştirma Süreci}

Araştırma; "Hazırlık” ve "Uygulama-Ürün Geliştirme” olmak üzere iki süreçten oluşmaktadır.

Hazırlık Süreci; 2007-2008 öğretim yılında yer alan Güz ve Bahar yarıyıllarının yanı sıra, 2008 yılının Yaz dönemini de kapsamıştır. 2007 - 2008 Güz Dönemi'nde araştırmanın meslek eğitimi ile ilgili alan yazın taramaları yapılmıştır. Bahar 
döneminde ise Grafik 1. sınıf öğrencileriyle araştırmanın pilot uygulaması gerçekleştirilmiştir. Pilot uygulama sürecinde; EEYO'da çıkarılmakta olan okul gazetesinin yayınlanması çalışması ile birlikte "Sayfa Tasarımı" dersi (toplam 40 saat), Grafik Tasarımı Meslek Dili I ve "Yazılı ve Sözlü Anlatım I" dersleri (toplam 35 saat) gerçekleştirilmiştir. Araştırmanın Geçerlik ve Güvenilirlik Komitesi'nce sağlanan geri bildirimlerle araştırmacı pilot uygulama sürecinde bir meslek öğretim elemanı olmanın yanı sıra bir dil dersi öğretim elemanı olarak da derslerini yürütmek üzere deneyim kazanmıştır (Mills, 2003).

Pilot uygulama sonucunda uygulamaya yönelik olarak araştrrma verilerinin EEYO'da var olan ve dönemlik olarak yayımlanan okul gazetesi yerine özgünlüğün sağlanması amacı ile çalışmanın ürünü olarak "dergi" yayınlanması planlanmıştır. Ayrıca Geçerlik ve Güvenilirlik Toplantılarında ders notlarının araştırmanın odak dersleri olan; "Sayfa Tasarımı", "Grafik Tasarımı Meslek Dili I", "Yazııı ve Sözlü Anlatım I" ve "Grafik Tasarım II” derslerinin tümünde kullanılmasına karar verilmiştir (17/09/2008 Tarihli İzleme Toplantısı). DOYÖY'ün ilkelerinden biri olan bu uygulama ile disiplinlerarası çalışma sağlanmıştır (Pressley ve diğ., 2002).

"Hazırlık" sürecinde elde edilen veriler doğrultusunda gerçekleştirilen Uygulama-Ürün Geliştirme süreci 2008-2009 öğretim yılı Güz Dönemini kapsamaktadır. Bu süreçte araştırma kapsamında; "Sayfa Tasarımı", Grafik Tasarımı Meslek Dili I, "Yazılı ve Sözlü Anlatım I" ve "Grafik Tasarım II" dersleri yapılmıştır. Meslek dersleri ile dil derslerinin işbirliğinin verimli olabilmesi amacıyla araştırma sürecinin izlendiği toplantılara dil derslerinden sorumlu olup, araştırmanın destek verisini toplayan öğretim elemanı da katılmıştır. Bu süreç içinde 11/09/2008 ile 23/12/2009 tarihleri arasında 11 kez Geçerlik ve Güvenilirlik Toplantısı yapıımıştır.

Uygulama-Ürün Geliştirme Süreci'nde öğrencilerin başlangıç performanslarını öğrenmek için yapılan Ön-Performans Değerlendirmesi 22/09/2008 tarihli "Sayfa Tasarımı" dersinde, derslerin tamamlanmasından sonra öğrencile-rin sonuç performanslarını öğrenmek için yapılan Son-Performans Değerlendirmesi ise 12/01/2009 tarihindeki "Sayfa Tasarımı" dersinde uygulanmıştır.

\section{Bulgular}

Makalenin bu bölümünde; Mesleki Eğitim Programları ve Dengeli Okuma Yazma Öğretimi ilkelerine göre işitme engelli üniversite öğrencileriyle mesleki eğitimde bir bilgisayar yazılımı kullanılarak gerçekleştirilen yayın çıkarma sürecinde oluşan model, modelin bileşenleri ve modelin işleyişinin incelenmesine yönelik bulgular aktarılacaktır.

\section{Yayın Çıkarma Süreci Modeli}

Araştırma sürecinde meslek dersleriyle dil derslerinin işbirlikli çalışması haftalık döngüsel bir modelle gerçekleştirilmiştir (Şekil 2).

Araştırma sürecinde oluşagelen model şu bileşenlerden oluşmuştur: "Sayfa Tasarımı", "Grafik Tasarım Meslek Dili I", "Yazılı ve Sözlü Anlatım I", "Grafik Tasarım II" ve "Ürün: Entegre Gençlik Dergisi”. Modelin bileşenleri karşılıklı olarak birbirini etkileyen, dinamik, senkronize ve döngüsel bir yapı içinde yer almaktadır.

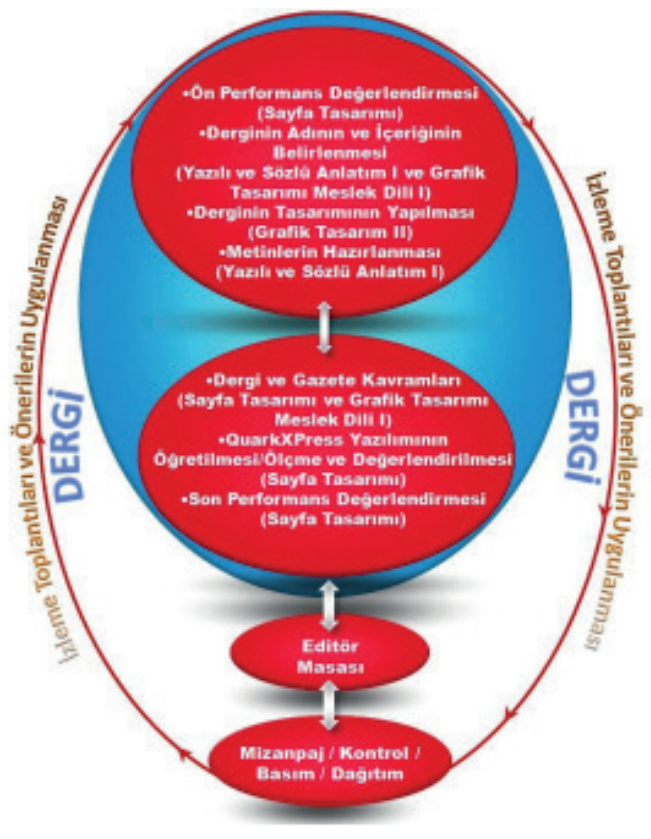

Şekil 2. Araştırma Modeli 
Modelin Bileşenleri ve Modelin İşleyişi

Araştırma sürecinde oluşagelen model (Şekil 2) meslek dersleri ve dil dersleri arasındaki işbirlikli çalışmalarla gerçekleştirilmiştir. Eylem araştırması yöntemiyle gerçekleştirilen araştırmadaki işbirliğinin haftalık döngüsü Şekil 3'de görülmektedir.

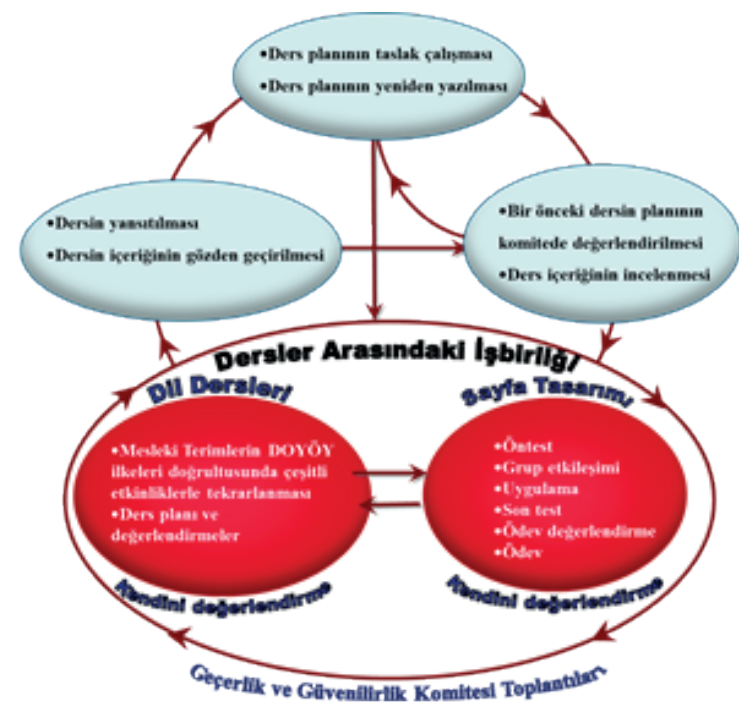

\section{Şekil 3. Haftalık İşbirliği Döngüsü}

Araştırmanın Uygulama-Ürün Geliştirme sürecinde gerçekleştirilen işbirliği araştrrmacılar, Geçerlik ve Güvenilirlik Komitesi ve "Grafik Tasarım II" dersinin öğretim elemanı arasında gerçekleştirilmiştir. İşbirliği çalışmasında; "Sayfa Tasarımı" dersini yürüten araştırmacı; ders materyallerini ve planlarını hazırlama, Geçerlik ve Güvenilirlik Komitesinin toplantılarına katılma, dersini uygulama, dil derslerinden sorumlu araşttrmacıyla ve "Grafik Tasarım II" dersinden sorumlu öğretim elemanıyla işbirliğini planlama ve gerçekleştirme çalışmalarını yürütmüştür. Süreç içindeki işbirliği; Geçerlik ve Güvenilirlik toplantılarıyla, araştırmacılar arasındaki telefon mesajları, e-postalar ve bireysel görüşmelerle, yansıtmalı değerendirmelerle ve eylem planlarıyla şekillenmiştir.

Modelin işleyişi; dersler (Sayfa Tasarımı, Grafik Tasarım Meslek Dili I, Yazılı ve Sözlü Anlatım I ve Grafik Tasarım II) ve ürün başlıklarında sunulmuştur.

Sayfa Tasarımı: Mesleki eğitim sürecinde uygulanan eğitim programının iş ortamlarında kullanılan uygulamaları içermesi gerekmektedir (Alkan, 1972; Berryman, 1991). Bu amaçla araştırmanın ürünü dergiye yönelik olarak araşttrmacının yürüttüğü ve modelin bileşenlerinden biri olan "Sayfa Tasarımı" dersi iki bölümde yürütülmüştür. Birinci bölümde dergi ve gazete kavramları çalışımıştır. İkinci bölümde ise QuarkXPress komutları çalışımıştır. QuarkXPress'in öğretildiği dersler iki aşamada gerçekleştirilmiştir. Dersin birinci aşamasında; QuarkXPress'in komutları çalışılışstr. İngilizce komutların tanınması, söylenmesi, tanımlanması, işlevinin anlatılması ve kullanımı ile ilgili araştırmacının model olması ve öğrencilerin katılımı ile ders yapılmıştır. Bu bölümde DOYÖY ve MEPi doğrultusunda dersler planlanmış ve uygulanmıştır. Araştırmacı öğrencilerin derse katılımları ile ilgili DOYÖY etkinlik ve stratejilerini kullanmıştır.

"Sayfa Tasarımı" dersinin ikinci aşaması izleyen etkinlik olarak yürütülmüştür. İzleyen etkinlik bölümünde öğrenciler kendile-rine verilen yönergeler doğrultusunda bilgisayar başında QuarkXPress'i kullanarak uygulama yapmışlardır. Öğrenciler QuarkXPress'i kullanırken araştırmanın amaçları doğrultusunda; öğrencilerin programın İngilizce komutlarını söylemeleri, işlevini anlatmaları ve komutları uygulamaları konusunda çalışmalar yapılmıştr. Araştırmacı bu amaç doğrultusunda planladığı "İzleyen Etkinlik" sürecinde öğrencilerden dersin birinci aşamasında öğrendikleri konuları bilgisayarda uygulama yaparak tekrar etmelerini istemiştir. İzleyen etkinlik sırasında öğrencilerin yanlarına giderek sorular sormuş ve öğrencilerin sözcükleri söylemelerini, komutları kullanmalarını ve komutların işlevlerini anlatmalarını istemiştir. Öğrenilen sözcüklerin ve komutların tekrarlanması amacıyla Zenginleştirme Etkinliği planlanmıştr. Zenginleştirme Etkinliği sürecinde öğrencilere derste öğrendikleri konuları içeren ödevler verilmiştir. Öğrenciler derste öğrendiklerini ders sonrasında araştırma ve uygulama yaparak çalışmışlardır. Yapılan çalışmalar dosyalanmış ve ödev notu ile değerlendirilmiştir (Jensen, 2011).

Grafik Tasarım Meslek Dili I: İşitme engelli öğrencilerin yeni sözcükleri öğrenmelerinde tekrarların önemi araştırmalarda vurgulanmaktadır (Albertini ve Schley, 2003; Conrad, 1979; Paul, 2003; Tompkins, 1997). İşitme engelli öğrencilerin mesleki eğitimleri sürecinde de meslek derslerinin dil dersleri ile desteklenmesi ve derslerin birbiriyle ilişkilen- 
dirilmesi, yeni öğrenilen sözcüklerin tekrarlanmasına ve farklı ortamlarda kullanımının sağlanmasına firsat vermektedir (Karasu G., 2011; Uzuner vd., 2011). Bu amaçla araştırma modelinin diğer bileşeni Grafik Tasarımı Meslek Dili I dersinde dergi-gazete kavramları ve QuarkXPress'in komutları "Sayfa Tasarımı" dersiyle eş zamanlı olarak çalışılmaya başlanmıştır. Grafik Tasarımı Meslek Dili I dersini yürüten dil dersi öğretim elemanıyla, "Sayfa Tasarımı" dersindeki mesleki sözcüklerin öğretiminde işbirliği yapılmıştır. Araştırmada dil dersinden destek alınmasının bir başka nedeni ise; "Sayfa Tasarımı” dersindeki mesleki sözcük sayısının çok ve bir bölümünün İngilizce olmasıdır. İngilizce sözcüklerin anlamı, Türkçe karşıllı̆ı ve okunuşu çalışması "Sayfa Tasarımı" dersinin yanı sıra yoğun olarak Grafik Tasarımı Meslek Dili I dersinde de DOYÖY ilkeleri doğrultusunda çalışılmıştır.

Yazılı ve Sözlü Anlatım I: Mesleki terminolojinin sadece Grafik Tasarımı Meslek Dili I dersinde çalışııması yeterli olmamıştr. Öğrencilerin öğrendikleri sözcükleri farklı ortamlarda görmeleri ve kullanmaları gerekmektedir. "Yazılı ve Sözlü Anlatım I" dersinde ilk haftadan itibaren; "Sayfa Tasarımı" dersinde kullanılan mesleki terminolojinin ders sürecinde kullanılarak pekiştirme çalışmalarının yanı sıra derginin içeriğini oluşturan yazıların hazırlanmasına yönelik çalışmalar yapılmıştr. Dil dersinden sorumlu öğretim elemanının yürüttüğü derste çok çeşitli konularda öğrencilerin yazma çalışması yapmaları sağlanmıştır. Öğrencilerin yazılarının dergide yayınlanacak olması öğrencilere gerçek amaç sunması yönüyle onları motive ettiği alanyazında belirtilmektedir (Lehr, 1995; Schley ve Stinson; 2016; Tompkins, 1997). Bu derste DOYÖY'ün ilkeleri doğrultusunda okuma ve yazma çalışmaları gerçekleştirilmiştir. Derginin içeriğini EEYO'nun tüm bölümlerinde ve sınıflarında yer alan "Yazılı ve Sözlü Anlatım" derslerinde öğrencilerle gerçekleştirilen yazma çalışmaları oluşturmuştur. Öğrencilerin hazırladıkları yazılar, yazı düzeltme çalışmalarından sonra dil dersi öğretim elemanları tarafindan dosyalanmıştır. Dönem sonunda (12/01/2009 tarihinde) "Editör Masası" toplantısı yapılmıştır. "Editör Masası" toplantısı dergide yer alacak tüm yazıların hangi sayfada yer alacağı ve sayfalara hangi tasarımların uygulanacağının belirlendiği toplantıdır. "Editör Masası" toplantısı dergi ve gazetelerin basıma hazırlanması aşamasında yapılmakta olan bir çalışmadır.

"Editör Masası" toplantısına; dil dersi öğretim elemanları ile "Sayfa Tasarımı" dersini yürüten araştırmacının yanı sıra "Sayfa Tasarımı" dersini alan gönüllü ve başarılı öğrenciler arasından seçilen öğrenciler katılmıştır. "Editör Masası" toplantısında getirilen haberler öğrencilerle seçilerek listelenmiştir. Haberlerin hangi öğretim elemanından geldiği listeye yazılmıştır (Şekil 4).
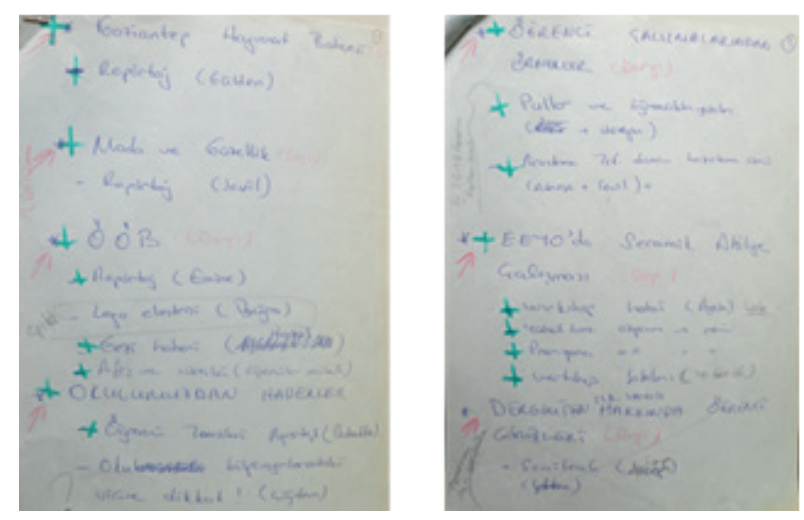

\section{Şekil 4. Dergide yer alacak yazıların belirlenmesi}

Dergide yer alacak yazılar belirlendikten sonra derginin tasarımına bakılarak her bir sayfaya hangi tasarımın uygulanacağı ve hangi sayfada hangi yazının yer alacağını belirleme çalışmasına geçilmiştir. Bu çalışma öğretim elemanlarının ve öğrencilerin görüşleri doğrultusunda gerçekleştirilmiştir.

Hazırlanan taslak dergi çalışmasında hem tasarım, hem de yazılar yer almıştır. Ayrıca yazıların yanına hangi öğretim elemanından geleceği ve hangi öğrencinin haberi olduğu yazılmıştır. Hazırlanan taslak derginin fotokopisi alınarak mizanpaj sürecinde öğrencilere dağıtılmıştır. 05/01/2009 tarihli "Editör Masası" toplantısında belirlenen yazıların tasarıma uygun olarak yapılan mizanpaj çalışması, 19/01/2009 tarihinde Grafik 1. Sınıf öğrencileri ve derginin tasarımcısının yanı sıra dil dersi öğretim elemanııı katlımı ve "Sayfa Tasarımı" dersini yürüten araştırmacının önderliğinde gerçekleştirilmiştir.

Grafik Tasarım II: İşbirliği yapılan "Grafik Tasarım II" meslek dersinde ise okul dergisinin tasarımı yapılmıştır. Mesleki eğitim programlarında dersler arasında yapılan anlamlı işbirliği çalışmaları öğrencileri gerçek ortamlara hazırlaması yönüyle önemi göz önünde bulundurularak araştırmanın ürünü okul dergisinin tasarımı için "Grafik Tasarım II" dersini yürüten öğretim elemanıyla işbirliği yapılmıştır (Berryman, 1991). 
Derginin tasarımına başlanabilmesi için öncelikle okul dergisinin adının ve içeriğinin belirlenmesi gerekmiştir. Bu amaçla 25/09/2008 tarihindeki “Grafik Tasarım II" dersinin ilk haftasında öğrencilere ödev olarak dergi tasarımı yapacakları duyurulmuş ve derginin adına yönelik ve genel olarak dergilerin tasarımları konularında araştırma yapmaları istenmiştir. Dersin ilk 5 haftası boyunca dergi tasarımı çalışması devam etmiştir. Tasarım çalışmasında Adobe Illustrator yazılımı kullanılmıştır. Dersin planı doğrultusunda ayrılan 5 haftalık süre boyunca öğrenciler dergi tasarımı üzerinde çalışmışlardır. Bu süreçte ilk hafta öncelikle dergi kavramları üzerinde çalışılmıştır. Kavram çalışmasından sonra derginin amblem ve logo tasarımı yapılmıştır. Daha sonra derginin sayfalarının tasarımı öğrenciler tarafindan yapılmıştır. Yapılan tasarımlar süreç içindeki haftalarda ilgili dersin öğretim elemanı tarafindan kontrol edilerek geri bildirim verilmiştir. Beşinci haftanın sonunda derginin tasarımı tamamlanmıştır.

Ürün (Entegre Gençlik Dergisi): Derginin tasarım çalışmasında; öncelikle araştırmanın ürünü olan derginin adı belirlenmiştir. Bu amaçla "Grafik Tasarım II" ve "Grafik Tasarım Meslek Dili I" derslerinin ilk haftasında yapılan ders etkinlerinde öğrenciler isim belirlemek amacıyla önerilerde bulunmuşlar daha sonra ortak kararla isimlerden bazıları seçilmiştir. Ön eleme yapıldıktan sonra oluşturulan listeden dersin öğretim elemanının yol gösterimiyle ve müdürün onayıyla bir isim seçilmiştir. Bu çalışma sonucunda derginin adı "Entegre Gençlik" olarak belirlenmiştir. Derginin adını belirleme çalışmaları devam ederken aynı zamanda derginin içeriğinde bulunacak konularla ilgili olarak 08/10/2008 tarihinde Yüksekokul'da yer alan dil derslerini yürüten öğretim elemanlarının yanı sıra "Sayfa Tasarımı" dersini yürüten araştırmacı ile "Grafik Tasarım II" dersini yürüten öğretim elemanının da katıldığı bir toplant yapılmıştır. Bu toplantıda derslerin planları ve etkinlikleri doğrultusunda içerik çalışmasının taslağı oluşturulmuştur. İçerik çalışması dergi kapağı tasarımı için önemli bir adımdır. Yapılan çalışmada derginin kapağında yer alacak başlıklar belirlenmiştir. Bu çalışmadan sonra derginin tasarımı öğrenciler tarafından çalışılarak tamamlanmıştr.

Derginin tasarımı Grafik 3. Sınıf öğrencileri "Grafik Tasarım II" dersinin etkinliği olarak geçekleştirirken, derginin yazılarının tasarıma göre mizanpajının yapılması çalışması ise Grafik 1. Sınıf öğrencileri ile "Sayfa Tasarımı" dersi etkinliği olarak gerçekleştirilmiştir. Bu şekilde tüm okulun öğrencilerinin katkısının olduğu bir ürün ortaya çıkarılabilmiştir. Derginin mizanpaj çalışmasında öğrenciler sayfalara göre görevlendirilmişlerdir. "Entegre Gençlik" dergisi A4 büyüklüguünde sayfalardan oluşmaktadır. Derginin iç içe sayfaları ortadan basılan bir zımba ile birleştirilmiştir. Sayfaların ortadan birleştirilmesi için A3 sayfası yatay olarak kullanılmıştı. Bu durum öğrencilerin iki dergi sayfasını tek bir A3 sayfasına yapmalarını gerektirmiştir. Derginin sayfaları renkli olarak basılmıştır. Derginin gerçek bir dergiye benzemesi için gerekli tüm önlemler alınmıştır. Mesleki eğitim sürecinde sağlanan gerçek ortamların, eğitim sürecini olumlu etkilerken öğrencilerin motivasyonunu da artırdığı bilinmektedir (Alkan, Doğan ve Sezgin, 2001; Pea, 1989, Akt. Berryman, 1991). Mizanpaj için sayfaların büyüklüğü, boşlukları ve diğer tasarım kuralları tasarımcıdan alınarak kurallar listesi hazırlanmış ve öğrencilere dağıtılmıştır. Mizanpaj öncesinde 12/01/2009 tarihli "Sayfa Tasarımı" dersinde öğrencilerle derginin sayfaları ve kuralları ile ilgili bilgilendirme ve görevlendirme çalışması yapılmıştı. "Sayfa Tasarımı" dersine katılan 10 öğrenciden ikisi sayfalarda yer alan yazıları/resimleri dağıtmak ve mizanpajın tasarım kurallarına uygun yapılıp yapılmadığını kontrol etmek için görevlendirilmiştir. Geriye kalan 8 öğrencinin her biri 4 dergi sayfası (2 adet A3 sayfası) yapmakla görevlendirilmiştir.

Öğrencilerin hangi sayfaları yapacakları sınıfta kura çekilerek belirlenmiştir. Yapılacak sayfalar tahtaya yazılmış ve kurada çıkan öğrenciler sayfalarla eşleştirilmiştir. Derginin sayfalarının tasarımı gereği QuarkXPress yazılımında açılan sayfalar enine kullanılacak şekilde ayarlanmıştır. Enine kullanılacak şekilde açılan A3 büyüklüğündeki sayfaya yanyana iki dergi sayfası yapılmıştır. Ancak sayfalar üst üste konulduğunda sıralı olmaları için her bir dergi sayfasının karşısında yeralan diğer sayfa derginin farklı numaradaki sayfasını oluşturmuştur. Örneğin; 1. Sayfayı yapan öğrenci yan sayfada 34. Sayfayı yapmıştır. Bu durum birbirini takip eden sayfaların farklı öğrenciler tarafindan yapılmasını gerektirmiştir. Bu çalışma öğrencilerin birbirileri ile iletişim kurmalarını ve birbirlerinden öğrenmelerini sağlarken, mesleki terminolojiyi kendi aralarında kullanmalarına da olanak vermiştir (Vygotsky, 1978). Öğrenciler derginin sayfalarını yaparken birbirini takip eden sayfalardaki uyumu sağlamak amacıyla birbirleriyle işbirliği yapmışlardır. Örneğin; bir öğrenci 1. ve 34. sayfayı kendisi yaparken, 1. sayfanın karşısında bulunan 2. sayfayı yapan öğrenci ile sayfanın karşılıklı oranları, resimlerin birbirini takip etmesi, renklerin uyumu, resim ve yazıların uyumu gibi konularda işbirliği yapmıştır. 2. sayfayı yapan öğrenci ise sayfasının karşında yer alan 33. sayfa için bu sayfayı yapan öğrenci ile işbirliği yapmıştır.

İşbirliği yapılacak sayfalar ve işbirliği yapacak öğrencilerin listesi mizanpaj öncesinde öğrencilere dağıtılmışttr. Öğrencilerin birlikte çalışması QuarkXPress yazııımının ve dergi kavramlarını sözlü dillerinde kullanmalarına olanak vermesi yönüyle önemlidir. Yapılan çalışmaya DOYÖY ve MEPi açısından bakıldı̆̆ında aşağıdakilerin sağlandığı görülmektedir (Collins, 1994; Schirmer, 2000).

- Öğrencilerin sözlü olarak mesleki terminolojiyi kullanmalarına firsat verilmesi, 
- Mesleki ortamlara benzer gerçek ve anlamlı ortamlar yaratılması,

- Öğrencilere sahiplenme için şans verilen ortamlar yaratılması,

- Mesleki anlamda daha iyi gelişen öğrencilerin daha az gelişen öğrencilere model olarak işbirliği yapmalarına firsat verilmesi,

- Dersler arasında işbirliği yaparak bütünleştirme ortamının oluşturulması,

- Öğrencilerin öğrendiklerinden haberdar olduğu bir eğitim ortamı yaratılması

- Eğitimleri sürecinde dergi içindeki yazıların yazımında ve birbirlerinin yazılarını okuyup düzenleyerek daha iyi okur yazarlar olmalarının sağlanması,

Aynı zamanda SCANS raporunda belirtilen temel beceri ve niteliklerinde oluşturulmasına yönelik çalışmalara izin verdiği de gözlenmiştir (Alkan, Doğan ve Sezgin, 2001; Pea, 1989. Akt. Berryman, 1991; OECD, 2010; SCANS, 1991). İşbirliği ile yapılan ve birbirini takip eden sayfaların içerikleri ve yapımı ile ilgili örnekler aşağıda sunulmuştur:

Derginin Sayfalarına Örnek: Araştırma ürünü derginin sayfalarından örnek olarak 1.-34. ve bu sayfaları tamamlayan 2. ve 33. sayfalar seçilmiştir. Dergi içinde birbirini tasarım ve haber olarak tamamlayan sayfalar yoğun olarak bulunmaktadır. Ancak bazı sayfalarda bu etkileşim çok, bazı sayfalarda ise daha azdır. Örnek etkileşimin en çok yaşandığı sayfalar arasından seçilmiştir. Derginin 1. ve 34. sayfalarını içeren mizanpaj "Nimet" tarafindan yapılmıştı (Şekil 5). 1. sayfada tasarımcının yaptığı ve resim biçimine (jpeg) dönüştürdüğü çalışma sayfanın tamamına açılan resim alanının içine tasarımın ölçüleri doğrultusunda yerleştirilmiştir. 34. Sayfada ise hem yazı alanı hem de resim alanı açılarak tasarıma uygun mizanpaj gerçekleştirilmiştir. Kullanılan arka plan rengi tasarımcının belirlediği renk olarak tanımlanmıştır. Yazıların fontu ve puntosu da yine tasarımda belirtildiği gibi yapılmıştır. Karşılıklı sayfaların uyumu mizanpaj açısından önemlidir.

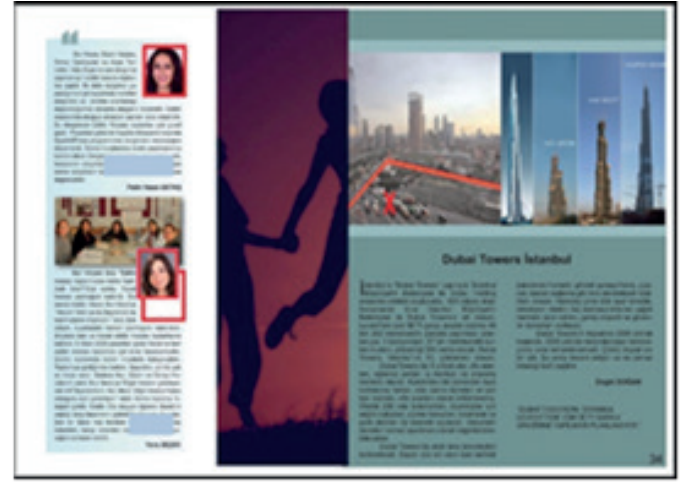

Şekil 5. Mizanpajı Nimet tarafindan yapılan 1. ve 34. sayfalar

Bu çalışmasında Nimet 2. ve 33. sayfayı yapan Muhsine ile birlikte çalışmıştır. Muhsine'nin yaptığı sayfa Şekil 6'da görülmektedir.

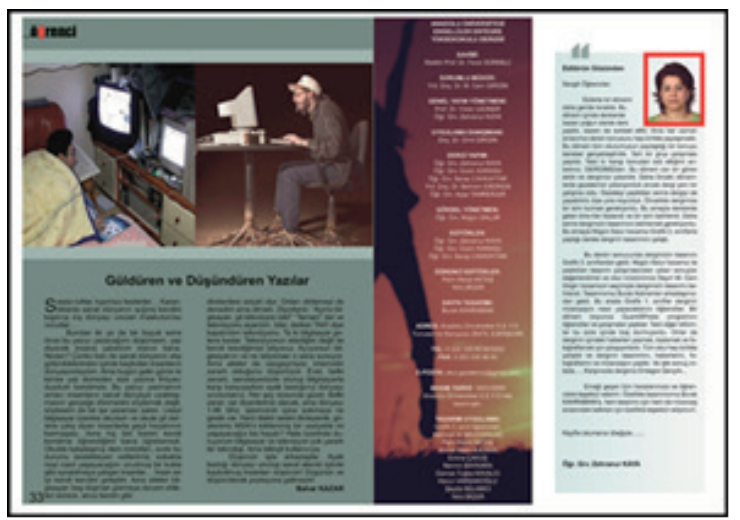

\section{Şekil 6. Mizanpajı Muhsine tarafindan yapılan 2. ve 33. sayfalar}

Muhsine'nin çalışması ile Nimet'in çalışması birbirini tamamlayan sayfalardır. 1. ve 2. sayfalardaki resimlerin birbirini tamamlaması, 33. ve 34. sayfalardaki renklerin uyumu, tasarımın devamlılığı, font ve puntoların görsel uyumu çalışmalarının gerçekleştirilmesi gereklidir. Öğrencilerin birlikte çalışarak yaptıkları bu çalışma öğretim elemanı tarafindan incelenmiş ve uyumlu olduğu belirtilmiştir. Öğrencilerin yaptğı̆ mizanpaj çalışmasının uyumu Şekil 7'de görülmektedir. Derginin mizanpaj çalışması odak derslerde final sınavı olarak değerlendirilmiştir. 


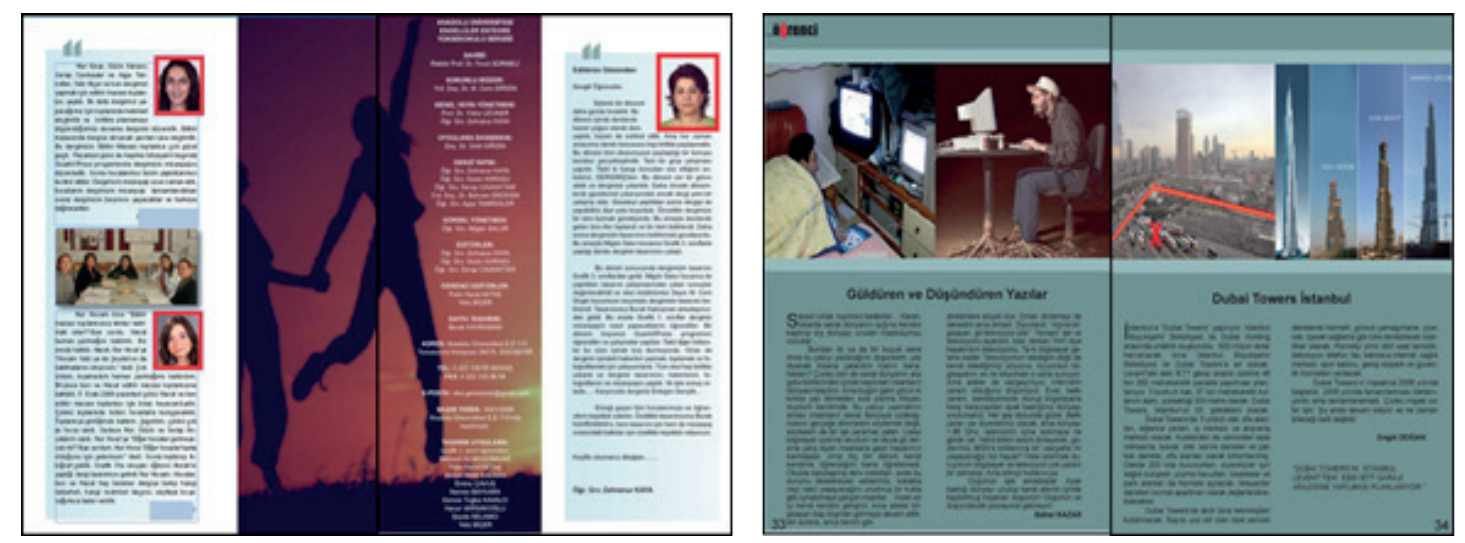

Şekil 7. 1. ve 2. ve 33. ve 34. sayfaların karşılıklı uyumu

\section{Sonuçlar}

Mesleki eğitim sürecinde işgücünden beklenen temel yeterlilik ve temel becerilere bakıldığında; mesleki bilginin bulunması ve yorumlanması, mesleki eğitim içinde yer alan karmaşık sistemlerin anlaşılabilmesi, farklı teknolojilerin kullanılabilmesi, mesleki bilginin yer aldığı metinlerin okunup anlaşılabilmesi, mesleki bilginin yazılı olarak düzenlenebilmesi gibi özelliklere sahip olunmasının beklendiği görülmektedir (OECD, 2010; SCANS Report, 1991). Öğrencilerin bu özelliklere sahip olabilmeleri için mesleki okuma-yazma becerilerinin geliştirilmesi önem taşımaktadır.

İşitme engelli öğrencilerin okuma ve yazma gelişimlerinin işiten akranlarından geride olduğu ve bu durumun öğrencilerin yaşları büyüdüğü zaman geliştiği düşünülmekle birlikte değişmediği araştırmalarda vurgulanmaktadır. Ancak yapılan araştırmalarda; bu durumun işitme engelli öğrencilerin ihtiyaç ve düzeylerine uygun etkili eğitimle değişebileceği de belirtilmiştir (Karasu, G., 2011; Uzuner vd., 2011). Etkili bir mesleki okuma-yazma ancak; amaçlı, işlevsel ve anlamlı bir meslek dilini içeren okuma-yazma ortamı sağlandığında mümkün olabilmektedir (Ör: Schirmer, 2000; Uzuner vd., 2011). İ̧̧itme engelli gençler için hazırlanacak mesleki eğitim programlarının içeriğinde mesleki eğitimin ilke, hedef ve amaçları doğrultusunda DOYÖY'ün ilke ve unsurlarından yararlanılabilir.

İşitme engelli öğrencilerin meslek derslerinde öğrendikleri bilgileri tekrar edebilmeleri ve bilgiler arasında ilişki kurabilmeleri için meslek dersleri ile dil derslerinin birbirini destekler biçimde yapılması planlanabilir. Bu amaçla kurgulanan örneğin; okulda yayıncılık çalışması ile tüm öğrenciler ürüne katılabilir ve farklı metin türlerinde okuma ve yazma çaış̧maları yapabilir, birbirleriyle iletişim kurabilir, görüşmeler yapabilir, araştırmalarını raporlaşttrabilirler (Wang, 2008). Araştırmada bu bilgiler ışığında çalışmalar gerçekleştirilmiştir. Yapılan çalışmalar sonucunda mesleki eğitim sürecinde bir model oluşa gelmiştir. Oluşa gelen modelin bileşenleri karşılıklı olarak birbirini etkileyen, dinamik, senkronize ve döngüsel bir yapı içindedir. Araştırmada gerçekleştirilen yayıncılık çalışması halen devam etmektedir. "Sayfa Tasarımı" dersi ile "Grafik Tasarım Meslek Dili I" dersinin işbirliği sürdürülmektedir. İşbirliği çalışması bu derslerin dışında farklı derslerde farklı öğretim elemanları arasında yapılarak çeşitli projelerle desteklenerek sürdürülmektedir.

Araştırmanın bulgularında; sürecin sonunda meslek dersinde öğrenilen bilgisayar yazılımına yönelik öğrencilerin; yazııımı uygulama becerilerinin ve yazılımın mesleki dilini kullanma becerilerinin geliştiği görülmüştür. Araştırmada DOYÖY ve Mesleki Eğitim Programlarının Illkeleri doğrultusunda uygulanan işbirlikli eğitimin; işitme engelli Yüksekokul öğrencilerinin mesleki dil, mesleki yeterlik ve becerilerinin gelişimine olumlu yönde katkı sağladığı görülmüştür. Araştırma sürecinin ürünü olarak ortaya çıkan "Entegre Gençlik" dergisinin öğrencilerin okuma-yazma becerilerinin gelişmesine olanak sağladığı görülmüştür. Dergi sürecinin gerçek yaşantlları sağlaması bakımında öğrencilerin bu süreci takip etmesi ve içinde etkin bir şekilde yer almaları öğrencilerin mesleki gelişimleri açısından faydalı olmuştur. DOYÖY ve Mesleki Eğitim Programlarının İlkelerinin sağlanmasına yönelik çalışmalarda kullanılan strateji ve etkinliklerin; öğrencilerin mesleki sözcükleri öğrenmelerine, mesleki becerilerini geliştirmelerine, mesleki bilgiyi akranlarına ve öğretim elemanlarına aktarmalarına olanak sağlaması açısından yararlı olduğu görülmüştür.

\section{5. Öneriler}

İşitme engelli bireylere yönelik koklear-implant uygulamaları onların sözel eğitime erken başlamalarını ve işiten akranları ile aynı ortamlarda eğitim almalarına katkı sağlamaktadır. Ancak yapılan araştırmalarda halen okuma-yazma

| Kastamonu Eğitim Dergisi, 27(5), 2019| 
becerileri yönüyle akranlarından geri kaldıkları görülmektedir (Karasu H.P., Girgin ve Uzuner, 2012). Bu durum işitme engellilerin mesleki eğitiminde önemli bir sorun olarak karşımıza çıkmaktadır. Mesleki bilginin edinilmesi, geliştirilmesi ve güncellenmesi okuma-yazma ve anlama becerilerinin geliştirilmesi ile mümkün olabilecektir. Bu amaçla işitme engelli bireylerin mesleki eğitimine yönelik gerçekleştirilen ve DOYÖY ve MEPi doğrultusunda hazırlanan uygulamaların yer aldığı bu araştırma; farklı yöntemlerle, farklı gruplarla ve farklı etkinliklerle sınanarak yeni araştırmaların desenlenmesi önerilebilir.

Mesleki terminolojinin öğretilmesine yönelik olarak değişkenler arasındaki neden sonuç ilişkilerinin belirlenmesine yönelik yarı deneysel, deneysel ve tek denekli araştırmalar planlanabilir. Mesleki eğitim veren ortaöğretim kurumlarına yönelik, işitme engelli öğrencilerin mesleki eğitimleri ile ilgili bilgi verici kitaplar, web sayfaları ve e-kitapların hazırlanmasına yönelik araşttrmalar desenlenmesi önerilebilir.

\section{Kaynakça}

Akçamete, G. (1999). Improving question skills for students with hearing impairment. Europan Journal of Special Needs Education. 14(2). 171-177.

Albertini, J. A. \& Schley, S. (2003). Writing, characteristics, instruction and assessment. Marschark, M. ve Spencer, E. P. (Eds.) Oxford handbook of deaf studies, language and education içinde (p. 123-135) New York, NY: Oxford University Press, Inc.

Alkan, C., Doğan, H. \& Sezgin, S.i. (2001). Mesleki ve teknik eğitimin esasları. Ankara: Nobel Yayın Dağıtım.

Alkan, C. (1987). Öğrenme-öğretme süreçleri ilkeleri. Ankara Üniversitesi Eğitim Bilimleri Fakültesi Dergisi. 20(1). 209-229.

Alkan, C. (1974). Eğitim teknolojisi. Ankara Üniversitesi Eğitim Bilimleri Fakültesi Dergisi. 1(7). 339-344.

Asselin, M. (1999). Balanced literacy. Teacher Librarian. 27(1), 69-70.

Avrupa Komisyonu (European Commission). (2007). Erişim tarihi: 04 Mayıs 2012, www.esae.org/articles/ 2007_08_005.pdf

Baumann, J. F. \& Kameenui, E. J. (2004). Vocabulary instruction: research to practice. New York, London: The Guildfor Press.

Berryman, S.E. (1991). Designing effective learning environments: cognitive apprenticeship models. William T. Grant Foundation Commission on Work. New York: Columbia University Institue on Education and Economy.

Biber, S. \& Leavy, P. (2011). The practice of qualitative research. USA: SAGE Publications Inc.

Bogdan, R.C. \& Biklen, S.N. (2007). Qualitative research in education an introduction to theaory and methods. Needham Heights, MA: Allyn and Bacon, Inc.

Buehl, D. (2001). Classroom strategies for interactive learning. Wisconsin, USA: International Reading International Reading Association.

Campbell, C.P. (1997). Training the workforce: an alternate approach. Vocational-Technical Education Conference, Lousville. 2-26.

Carnine, D. W., Silbert, J. ve Kameenui, E. J. (1996). Direct instruction reading. (3rd. ed.). New Jersey, Columbus, Ohio: Pearson Merrill Prentice Hall.

Center, Y. (2005). Begining reading a balanced apporach to teaching literacy during the first three years at school. London: Continuum International Publishing Group.

Collins, N. D. (1994). Metacognition and learning to read. ERIC Clearinghouse on Reading English and Communication Bloomington IN. Erişim tarihi: 13 Ekim 2011, http://www.vtaide.com/png/ERIC/Read-to-Learn.htm

Conrad, R. (1979). The deaf school child. London: Harper and Row.

Cramer, R.L. (2004). The language arts a balanced approach to teaching reading, writing, listening, talking and thinking. USA: Pearson Education, Inc.

Creswell, J.W. (2005). Educational research planning, conducting, and evaluating quantative ana qualitative research. Pearson Prentice Hall.

Derican, T. (2010). İsitme engelli gençlere iş başvurusu dosyası (portfolyo) geliştirme çalışmalarının incelenmesi: Eylem araştırması. (Yayınlanmamı̧ Yükseklisans Tezi). T.C. Dumlupınar Üniversitesi Sosyal Bilimler Enstitüsü, Kütahya.

Disability Statistics Compendium. (1990). Erişim tarihi: 04 Mayıs 2012 http://unstats.un.org/unsd/aboutus.htm

Engelliler Entegre Yüksekokulu (1993). Erişim tarihi: 23 Aralık 2009, http://www.anadolu.edu.tr/akademik/yuksek_okullar.aspx\#yo_engent Fer, S. (2000). Modüler program yaklaşımı ve bir öneri. Eğitim Sanat Kültür Dergisi. Milli Eğitim Bakanlığı Yayınları. 147, Ankara.

Ferrance, E. (2000). Themes in education. Action research. LAB. A program of the Education Alliance. Northeast and Islands Regional Educational Laboratory at Brown University.

Fidan, N. (1997). Eğitim Psikolojisi Okulda Öğrenme ve Öğretme. Alkım Yayınevi. Ankara.

Fountas, I.C. \& Pinel, G.S. (1996). Guided reading, good first teaching for all childen. Heinemann, Portsmouth, USA.

Gay, L.R. , Mills, G.E. \& Airasan, P. (2006). Education research competencies for analysis ana applications. Pearson Prentice Hall.

Girgin, Ü. (1999). Eskişehir ili ilkokulları 4. ve 5. sınıf iş̧itme engelli öğrencilerinin okumayı öğrenme durumlarının çözümleme ve anlama düzeylerine göre değerlendirilmesi. Eskişehir: Anadolu Üniversitesi Yayınları.

Graham, L. \& Wong, B.Y.L. (1993) Comparing two modes in teaching a question answering strategy for enhancing reading comprehension: Didactic and self instructional training. Journal of Learning Disabilities. 26(4), 270-279.

Hagood, B. E. (1997). Reading and writing with help from story grammar. Teaching Exceptional Children. March/April, 10-14 
Harrel, A. \& Jordan, M. (2002). 50 active learning strategies for improving reading comprehension. Ohio: Merril Prentice Hall.

Henning, J.E., Stone, J.M. \& Kelly, J.L. (2009). Using action research to improve instruction. London.

Hiebert, E. H. \& Kamil, M. L. (2005). Teaching and learning vocabulary: Bringing research to practice. New Jersey, London. Lawrence Erlbaum Associates, Publisher.

İçden, G. (2003). Üniversite hazırlık sınıfi işitme engelli öğrencilerinin okuma sonrası soruları yanıtlamalarında "Soru Yanıt ilişkileri" stratejisinin kullanımı. (Yayımlanmamış Yüksek Lisans Tezi). Anadolu Üniversitesi Eğitim Bilimleri Enstitüsü, Eskişehir.

Irvin, J.L., Buehl, D.G \& Klemp, R.M. (2007). Reading and the high school student strategies to enhance literacy. Pearson. USA.

Jensen, E. (2011). Erişim tarihi: 22 Kasım 2012 http://www.education.com/reference/article/enrichment-specialist/

Kameenui, J.E. \& Simmons, C.D. (1990). Designing instructional strategies: The prevention of academic learning problem. Columbus, Ohio: Merrill Publishing Company.

Karasu, G. (2011). İşitme engelli gençlere uygulanan sözcük dağarcığı geliştirme stratejilerinin incelenmesi. (Yayımlanmamış Doktora Tezi). Anadolu Üniversitesi Eğitim Bilimleri Enstitüsü, Eskişehir.

Karasu, H.P. \& Girgin, Ü. (2007). Kaynaştırmadaki işitme engelli çocukların yazılı anlatım becerilerinin değerlendirilmesi. Anadolu Üniversitesi Sosyal Bilimler Dergisi, 7(1), 467-488.

Lehr, F. (1995). Revision in the writing process. Clearinghouse on Reading English and Communication Bloomington IN. Erişim Tarihi: Kasım 2017, http://files.eric.ed.gov/fulltext/ED379664.pdf

Luckner, J. L. \& Handley, C. M. (2008). A summary of the reading comprehension research undertaken with students who are deaf or hard of hearing. American Annals of the Deaf, 153(1), 6-35.

Mager, R.F. \& Beach, K.M. (1967). Developing vocational instruction. Belmont, California: Fearon-Pitman Publishers, Ins.

Mills, G. E. (2003). Action research. a guide for the teacher researcher. Upper Saddle River, NJ: Pearson Education, Inc.

Nagy, W. E. (1988). Teaching vocabulary to improve reading comprehension. Newark, DE: International Reading Assn.

OECD. (2010). Learning for job. OECD Reviews of Vocational Education and Training. OECD Publications.

Paul, .P.V. (2003). Processes and components of reading. (İçinde) Marschark, M. ve Spencer, E. P. (eds.) Oxford Handbook of Deaf Studies, Language and Education. (p: 97-109) New York, NY: Oxford University Press, Inc.

Pearson, P.D., Raphael, T.E., Benson, V.L. \& Madda, C.L. (2007). Best practices in literacy instruction. Balance in Comprehensive Literacy Instruction: Then and now. Newyork London: The Guiltford Press.

Prosser, C.A. \& Quigley, T.H. (1949). Vocational education in a democracy. Chicago, USA: American Technical Society.

Reutzel, D. R. \& Cooter, R. B. (1999). Balanced reading strategies and practices: Assesing and assisting readers with special needs. Upper Saddle River, NJ: Merril Prentice Hall.

Rief, S.F. \& Heimburge, J.A. (2007). How to reach and teach all children through balanced literacy. PB Printing: USA.

Rupley, W. H., Blair, T. R. \& Nichols, W. D. (2009). Effective reading instruction for struggling readers: The Role of Direct/Explicit Teaching. Reading ve Writing Quarterly. 25. 125-138.

Ryen, A. (2011). Qualitative research. Silverman, D. (Ed.). Ethics and Qualitative Research içinde. p.416-438. London: SAGE Publication Inc.

Schley, S. \& Stinson, M. A. (2016). Collaborative writing in the postsecondary classroom: Online, in-person, and synchronous group work with deaf, hard-of-hearing, and hearing students. Journal of Postsecondary Education and Disability, 29(2), 151-164. Schirmer, R. B. (2000). Language and literacy development in children who are deaf. Boston: Allyn and Bacon, Inc.

Schirmer, B.R. (2010). Teaching the struggling reader. Pearson: USA

Sezgin, S.i. (1994). Mesleki ve teknik eğitimde program geliştirme. Ankara: Gazi Büro Kitabevi.

Scans Report (1991). What work requires of schools. Erişim Tarihi: 22 Kasım 2012, https://wdr.doleta.gov/SCANS/whatwork/whatwork.pdf

Thompson, J.A. (1981). So you have a hearing impaired student in your vocational education classroom (a prototypic resource unit). Washington D.C.: Kent State University Ohio Collage of Education Project SAVE.

Tompkins, G. (1997). Literacy for the 21st century, A balanced approach. New Jersey: Prince Hall Inc.

Tüfekçioğlu, A. U. (1998). Farklı eğitim ortamlarındaki işitme engelli öğrencilerin konuşma dillerinin incelenmesi. Eskişehir. Eğitim Sağlık ve Bilimsel Araştırma Çalışmaları Vakfi Yayınları, Yayın No:141

Uzuner, Y., İçden, G., Girgin, Ü., Beral, A. \& Kırcaali-iftar, G. (2005). An examination of impacts of text related questions on story grammer acquisition of three Turkish youths with hearing loss. The International Journal of Special Education. 20(2). 111-121.

Uzuner, Y., Girgin, Ü., Kaya, Z., Karasu, G., Girgin, C., Erdiken, B., Cavkaytar, S. \& Tanrıdiler, A. (2011). İşitme engelli gençlere uygulanan Dengeli Okuma Yazma Öğretimi modelinin incelenmesi. Kuram ve Uygulamada Eğitim Bilimleri. 11(4), 2111-2132.

Walker, L., Munro, J., \& Rickards, F. W. (1998). Literal and inferencial comprehension for student who are deaf or hard of hearing. The Volta Review. 100(2), 87-104.

Wang, S. (2008). Encyclopedia of information technology curriculum integration. Desktop Publishing in Education. Idea Group Inc (IGI).

Vygotsky, Y. (1978). Mind in society: The development of higher psychological processes. (Ed. M. Cole, V. John-Steiner. S. Scribner \& R. Sourberman). Cambridge: MA: Harvard University.

Yılmaz, H. (2004). Eğitimde ölçme ve değerlendirme. Konya: Cizgi Kitapevi Yayınları.

| Kastamonu Eğitim Dergisi, 27(5), 2019| 